\title{
Currently Applied Molecular Assays for Identifying ESR1 Mutations in Patients with Advanced Breast Cancer
}

\author{
Nuri Lee ${ }^{1}$, Min-Jeong Park ${ }^{1}\left(\mathbb{D}\right.$, Wonkeun Song ${ }^{1}{ }^{(\mathbb{C}}$, Kibum Jeon $^{2}$ and Seri Jeong ${ }^{1, *(\mathbb{D}}$ \\ 1 Department of Laboratory Medicine, Kangnam Sacred Heart Hospital, Hallym University College of \\ Medicine, Seoul 07440, Korea; nurilee822@hallym.or.kr (N.L.); mjpark@hallym.or.kr (M.-J.P.); \\ swonkeun@hallym.or.kr (W.S.) \\ 2 Department of Laboratory Medicine, Hangang Sacred Heart Hospital, Hallym University College of \\ Medicine, Seoul 07440, Korea; pourmythe45@hallym.or.kr \\ * Correspondence: hehebox@naver.com; Tel.: +82-845-5305
}

Received: 27 October 2020; Accepted: 19 November 2020; Published: 20 November 2020

\begin{abstract}
Approximately 70\% of breast cancers, the leading cause of cancer-related mortality worldwide, are positive for the estrogen receptor (ER). Treatment of patients with luminal subtypes is mainly based on endocrine therapy. However, ER positivity is reduced and ESR1 mutations play an important role in resistance to endocrine therapy, leading to advanced breast cancer. Various methodologies for the detection of ESR1 mutations have been developed, and the most commonly used method is next-generation sequencing (NGS)-based assays (50.0\%) followed by droplet digital PCR (ddPCR) (45.5\%). Regarding the sample type, tissue (50.0\%) was more frequently used than plasma (27.3\%). However, plasma (46.2\%) became the most used method in 2016-2019, in contrast to 2012-2015 (22.2\%). In 2016-2019, ddPCR (61.5\%), rather than NGS (30.8\%), became a more popular method than it was in 2012-2015. The easy accessibility, non-invasiveness, and demonstrated usefulness with high sensitivity of ddPCR using plasma have changed the trends. When using these assays, there should be a comprehensive understanding of the principles, advantages, vulnerability, and precautions for interpretation. In the future, advanced NGS platforms and modified ddPCR will benefit patients by facilitating treatment decisions efficiently based on information regarding ESR1 mutations.
\end{abstract}

Keywords: estrogen receptor; ESR1; breast cancer; next-generation sequencing; droplet digital polymerase chain reaction

\section{Introduction}

\subsection{Epidemiology of Breast Cancer}

A total of 2,179,457 new breast cancer cases and 655,690 cancer-related deaths were estimated worldwide in 2020 according to the Global Cancer Observatory compiled and disseminated by the International Agency for Research on Cancer [1]. Among women, breast cancer is the most frequently diagnosed cancer and the leading cause of cancer-related deaths in major countries. Moreover, the incidence rates of breast cancer exceed those of other malignancies in both transitioned and transitioning nations [2,3]. The age-standardized incidence rates are highest in Australia/New Zealand; western, northern, and southern Europe; northern America; and southern and eastern Africa [4]. These international distributions are associated with cultural and/or environmental changes due to industrialization. Changes in nutrition, anthropometry, age at menstruation, hormone intake, lactation, 
and reproductive patterns, including fewer children and later age at first birth, contribute to the epidemiology of breast cancer [5].

\subsection{Diagnosis and Molecular Heterogeneity of Breast Cancer}

With respect to diagnosis and treatment, breast cancer is one of the most heterogeneous and complex diseases. Several subtypes with distinct biological characteristics result in differences in response patterns to diverse therapeutic regimens and clinical outcomes. Traditional classification systems have been based on tumor size, lymph node involvement, histological grade, age, and estrogen receptor (ER), progesterone receptor (PR), and human epidermal growth factor receptor 2 (HER2) status [6]. Approximately 75\% of breast cancers are positive for ER and/or PR [6]. ER-positive tumors have responsive genes encoding typical proteins of luminal epithelial cells. Distinct intrinsic gene sets have been identified and combined into two main luminal-like subclasses corresponding to luminal A and luminal B to characterize the most common luminal subtype [7-10]. The luminal A subtype is defined as ER-positive and/or PR-positive, HER2-negative tumors with a low Ki-67 index [11]. Treatment of patients with luminal A breast cancer mainly involves endocrine therapy and has a good prognosis, with relapse and metastasis rates that are significantly lower than those of the other subtypes [12,13]. The luminal B subtype is defined as ER-positive, HER2-negative, with a high Ki-67 index or as ER-positive, HER-2-positive [14]. Luminal B cancers have a higher recurrence rate and lower survival rates than the luminal A subtype because they are relatively insensitive to endocrine therapy [15]. According to studies investigating molecular profiles [16,17], there are numerous subtype-associated gene mutations, including the enrichment of specific mutations in GATA3, PIK3CA, and MAP3K1 in luminal-type breast cancers. The biological findings of the main breast cancer subtypes caused by different subsets of genetic and epigenetic alterations support the clinical observations of plasticity and heterogeneity within these major biological subtypes of breast cancer. Generally, these luminal subtypes presenting ER $\alpha$ encoded by the ESR1 gene have a more favorable prognosis than those without. However, ER positivity was reduced 5-6 years after diagnosis, implicating an important role of resistance to endocrine therapy [18].

\subsection{Endocrine Therapy and Resistance}

Endocrine therapy has been recommended for patients with the luminal subtype of breast cancer [19]. Aromatase inhibitors, selective estrogen receptor modulators, and selective estrogen receptor degraders are major endocrine strategies for the treatment of ER-positive advanced breast cancers [20]. Aromatase inhibitors block the conversion of androgens to estrogens, resulting in lower levels of circulating estrogen and the resulting decreased stimulation of endocrine receptors. Selective estrogen receptor modulators such as tamoxifen bind both intracellular ERs and co-repressor proteins. It exhibits a partial ER $\alpha$ agonistic feature with net antagonistic activities on breast cancer tissue. Selective ER degraders, such as fulvestrant affect the stability of the ER and downregulate the receptor protein [21]. Although these medications reduce relapse rates when administered prophylactically after surgery and chemotherapy, resistance to endocrine therapy leading to the development of fatal metastatic cancer commonly occurs and has become a major clinical problem [22]. When approximately $15 \%$ of patients with ER-positive breast cancer relapse lose ER expression, targeting the ER is likely to be ineffective. The remaining $85 \%$ of patients might progress to metastatic status because of the inevitable acquired resistance. Resistance to endocrine therapy is an important driver of mortality due to metastasis to distant organs.

\subsubsection{Mechanisms of Resistance to Endocrine Therapy}

The mechanisms of resistance to endocrine therapy are complex and have been investigated previously [23]. Aberrantly activated growth factor receptor tyrosine kinases, such as epidermal growth factor receptor (EGFR) and HER2 (ERBB2) have increased ER transcriptional activity in a hormone-independent manner [24]. ER-positive cases that express ERBB2 amplification have reduced 
sensitivity to ER-targeted endocrine therapies, leading to poor outcomes [25]. However, clinical trials using EGFR inhibitors have shown modest or negative results [26]. Dysregulation of the cyclin $\mathrm{D}-\mathrm{CDK} 4 / 6-\mathrm{Rb}$ axis promoting resistance to endocrine therapy is frequently observed in the luminal B subtype [16,27]. CDK4/6 inhibitors, namely palbociclib and ribociclib, are approved for use in combination with endocrine therapy for treating advanced ER-positive cancers [28]. In particular, ESR1 was more frequently mutated in metastatic breast cancer than in early breast cancer and has been identified both as a driver and as a metastatic gene [29]. Alterations in ESR1, such as amplifications, point mutations, and chromosomal rearrangement events, have been identified as well-known mechanisms in driving endocrine therapy resistance and metastatic disease progression.

\subsubsection{ESR1 Mutation}

The ESR1 gene located at 6q25.1-q25.2 encodes an ER and a ligand-activated transcription factor consisting of several domains involved in hormone binding [30]. Related pathways include the estrogen signaling pathway and signaling by $G$ protein-coupled receptors, the large family of cell surface receptors [31]. Various ESR1 mutations are implicated in hormone resistance and anti-estrogen therapies, such as tamoxifen, aromatase inhibitors, and fulvestrant, in patients with ER-positive breast cancer [32-34]. Resistance to endocrine therapy derived from ESR1 can be classified into acquired and de novo patterns. ESR1 expression changes over time; thus, negative results at a point of disease evolution can become detectable at another time [20]. According to studies investigating ESR1 mutations, there is persistent activation of ER regardless of its ligand. A shift in helix 12 of ESR1, leading to the similarity to the estrogen-bound activated state of ER, was suggested as a mechanism for this ligand-independent ER activity. Coactivators may be able to bind and activate ER because of a change in ER configuration conferring resistance to endocrine therapy [35]. This mutational mechanism found in approximately $40 \%$ of patients with metastatic breast cancer who were pretreated with aromatase inhibitors [36,37]. Various ESR1 alterations, amplification, genomic rearrangement, and point mutations contribute to the therapeutic resistance and metastasis of ER-positive breast cancer.

\section{ESR1 Amplification}

ESR1 amplification is identified in approximately $30 \%$ of patients with ER-positive breast cancer depending on detection techniques and scoring systems [38-42]. A positive association between ESR1 amplification and ER protein expression demonstrated in several studies suggests that amplification results in the increased production of oncogenic ER proteins [41-43]. In terms of the clinical significance of ESR1 amplification, the link between the presence of ESR1 amplifications in breast malignancy and resistance to endocrine therapy leading to metastasis is not clear and needs further investigation. ESR1 amplification in a subset of ER-positive breast cancers was correlated with tamoxifen resistance and poor prognosis of patients $[18,44]$. In contrast, ESR1 amplification was suggested as an indicator of longer disease-free survival and elevated sensitivity to endocrine therapy in contradicting studies [42,45]. Further studies are necessary to fully understand the clinical implications of ESR1 amplifications owing to these controversial results.

\section{ESR1 Rearrangements and Fusion}

The genomic rearrangements of ESR1 have also been investigated. Diverse ESR1 gene fusion transcripts have been identified in luminal breast cancer cases [46,47]. According to a previous study, RNA-sequencing data from primary TCGA breast samples demonstrated that $2.1 \%$ of all luminal B subtype samples harbored recurrently fused transcripts. The identified transcripts involved in the first two non-coding exons of ESR1 fused to various C-terminal sequences from the coiled-coil domain containing 170 genes (CCDC170) (ESR1-e2 > CCDC170). These fusion transcripts generate truncated forms of CCDC170 proteins, which cannot complete chimeric ER fusion proteins. Therefore, exogenous expression of these truncated CCDC170 proteins in ER-positive breast cancer cells results in overgrowth and decreased sensitivity to tamoxifen [47]. This study presented a representative 
role for ESR1-e2 > CCDC170 in endocrine therapy resistance. In terms of metastatic ER-positive breast cancer, ESR1 fusions follow a similar fusion pattern harboring the first six exons of ESR1 (ESR1-e6) fused to the C-terminus of various gene partners. Therefore, this pattern is considered important for endocrine therapy resistance based on ESR1 fusion structural studies. However, detailed functional characterization and evidence supporting a causal role for ESR1 fusions have been lacking. Moreover, the incidence of ESR1 fusions is estimated at approximately $1 \%$, and the exact value has not yet been established [48]. Additional studies that provide evidence for the causal role of ESR1 fusions, as well as their significant diagnostic and clinical implications need to be performed. A recent study [49] showed a novel mechanism that ESR1-CCDC170 bound to HER2/HER3/SRC and activated SRC/PI3K/AKT signaling. Therefore, treatment regimens combining endocrine agents with the HER2 inhibitor lapatinib and/or the SRC inhibitor dasatinib might be applied to patients with ESR1-CCDC170 gene fusions. Furthermore, kinase fusions in breast cancer analyzed by Memorial Sloan Kettering-Integrated Mutation Profiling of Actionable Cancer Targets seemed to be enriched in hormone-resistant, metastatic carcinomas and mutually exclusive with ESR1 mutations [50]. Based on these results, fusion testing as a molecular testing at progression after endocrine therapy was suggested in an effort to identify additional therapeutic options which may provide substantial clinical benefit.

\section{ESR1 Point Mutation}

Among several mechanisms of ESR1 mutation, the acquisition of activating point mutations, which cluster within the ligand-binding domain (LBD) of ESR1, is a well-known mechanism for acquired endocrine therapy resistance. Substitution of tyrosine at position 537 to serine (Y537S) in the LBD of ESR1 conferring constitutive, ligand-independent activity of ER was first reported in experimental breast cancer models [51]. Regarding human tumors, Y537N was found in a metastatic specimen from a patient with breast cancer who experienced disease progression while on endocrine therapy [52], suggesting its ability to drive resistance to tamoxifen. The three most frequently identified ESR1 point mutations were D538G, Y537N, and Y537S [20,34]. ESR1 LBD point mutations mostly affect Y537 and D538 residues $[40,48]$. Samples from patients with ER-positive breast cancer treated with endocrine therapy rather than those from treatment-naïve patients revealed these mutations [48], supporting a role for ESR1 mutations in acquired resistance to endocrine therapy and metastasis [53].

In vitro studies have been performed to characterize the functional, transcriptional, and pharmacological properties of ESR1 LBD point mutations. Cell line models expressing ESR1 mutants showed that these mutants contribute to hormone-independent proliferation resistant to endocrine treatment $[34,40,54,55]$. These mutations are in an apo-receptor conformation, which are constitutively active, even upon antagonist binding $[34,56]$. Changes in protein structure derived from these ESR1 mutations resulted in reduced ligand affinity and ligand-independent activity. Although fulvestrant inhibited the growth of point mutation-containing cells in a dose-dependent manner, growth was not reversed to the levels of wild-type ESR1-expressing cell lines [40,54]. When bound to fulvestrant, the ESR1 mutant also showed enhanced protein stability compared to the wild-type receptor. Moreover, these ESR1 LBD mutations also recruited coactivators that further potentiated ER transcription [55,57]. In terms of metastatic biology, ESR1 mutant cell lines, including Y537S and D538G, presented a substantial enrichment of metastasis-associated gene sets. The Y537S mutant showed remarkably potentiated tumor growth and metastasis in patients treated with tamoxifen or fulvestrant compared to the D538G mutant because of different cistromes and transcriptomes [53]. Regarding signaling pathways activated by ESR1 mutants, interactions between ERs and receptor tyrosine kinases, including EGFR, HER2, and insulin-like growth factor receptor, activate downstream kinases. Particularly, co-localization and crosstalk between mutant ER and the insulin-like growth factor receptor pathway were revealed using ER immunoprecipitation and proximity ligation assays [58]. This upregulated insulin-like growth factor receptor pathway was demonstrated in ESR1 mutant overexpression models [32,59]. These related pathways induce phosphorylation of multiple transcription factors, such as ERs and co-factors, leading to gene expression in a hormone-independent manner [60], suggesting a role for 
mutant ERs in promoting a metastatic phenotype [53,61]. With respect to the therapeutic strategy for preventing ESR1 mutant-driven breast tumors, targeting these signaling pathways could be considered. According to a recent study [62], the emergence of circulating ESR1 mutations was related to the risk of early progression during aromatase inhibitor treatment in patients with metastatic breast cancer, which suggested the potential role of ESR1 mutations as a useful biomarker. In addition, the immunogenicity of epitope derived from the most common ESR1 mutations including D538G and Y537S was suggested as novel targets for breast cancer immunotherapy [63].

\subsection{Aims of This Review for Molecular Assays}

Several molecular methods have been developed and evaluated for these ESR1 mutations that are strongly involved in breast cancer development and progression [20,64]. Variations in different assays used in diverse studies affect their results and clinical utility. When adopting these assays, a comprehensive understanding of the principles, advantages, disadvantages, and precautions for data interpretation should be well-recognized. Articles focusing on laboratory methods for evaluating ESR1 mutations have been rarely published. Therefore, our study reviews molecular assays for ESR1 mutations, the main cause of advanced estrogen-positive breast cancer with resistance to endocrine therapy. Advances in techniques according to the epoch are also investigated based on published articles for gaining insight into molecular methodologies and for facilitating appropriate laboratory settings for evaluating ESR1 mutations, which are useful for predicting outcomes and planning patient-tailored therapeutic strategies.

\section{Sample Type}

The sample types obtained from patients with breast cancer for detecting ESR1 mutations using molecular assays are presented in Table 1. Twenty-two included studies were from three recently published systematic reviews and meta-analyses [20,64,65] reporting ESR1 mutations in advanced breast cancers with resistance to endocrine therapy. The most frequently used sample type was tissue (50.0\%), including formalin-fixed paraffin-embedded (FFPE) $(66.7 \%)$ and fresh frozen (25.0\%) tissues (Figure 1a). Archival FFPE tissues have been a powerful resource for NGS studies [66]. However, formalin fixation results in intra- and inter-molecular crosslinks. These crosslinks create difficulties in efficient DNA extraction and amplification. Acidic and non-buffered formalin also induces DNA fragmentation. Sequence artifacts, such as an increase in the $C>T / G>A$ change at low to moderate allele frequency levels of $<10 \%$, have been observed $[67,68]$. Therefore, evidence-based best practices for FFPE DNA extraction provided by the National Cancer Institute [69] and European Committee for Standardization Technical Specifications on the pre-analytical phase of FFPE DNA have been published [70]. Tissue ischemia time and temperature, fixation time, storage conditions of the FFPE blocks and DNA extraction, and pre-normalization concentration of libraries should be carefully considered based on previous studies [71]. Among several kits for tissue DNA extraction, QIAamp DNA FFPE Tissue Kit and DNeasy Blood \& Tissue Kit from Qiagen [70] are the most frequently used.

Plasma samples in K2/K3 ethylenediaminetetraacetic acid (EDTA), Streck Cell-free DNA blood collection, and heparinized tubes accounted for $27.3 \%$ of the sample type. The concurrent use of tissue and plasma specimens constituted $22.7 \%$ of the total sample types. Although heparinized tubes have been used in some studies, they are not recommended for polymerase chain reaction (PCR) because heparin is a well-known inhibitor, and residual heparin can influence PCR amplification [72]. According to a study comparing cell-free DNA (cfDNA) in different types of tubes, significantly higher cfDNA concentrations were detected in EDTA samples than in heparinized samples. Moreover, cfDNA concentrations were more stable over time within the EDTA matrix than heparin [73]. EDTA blood should be processed within 2-6 h at room temperature and should be kept frozen at $-20{ }^{\circ} \mathrm{C}$ or $-80^{\circ} \mathrm{C}$ for longer than $24 \mathrm{~h}[74,75]$. Streck Cell-free DNA blood collection tubes provided by Streck Inc. showed even more stable plasma cfDNA concentrations after storage for 2-14 days than EDTA tubes [76,77]. These tubes are strongly recommended, particularly for multicenter NGS studies because 
of their beneficial effect on plasma cfDNA [73]. Among studies using droplet digital PCR (ddPCR), the QIAamp circulating nucleic acid kit was most commonly used for DNA extraction.

a

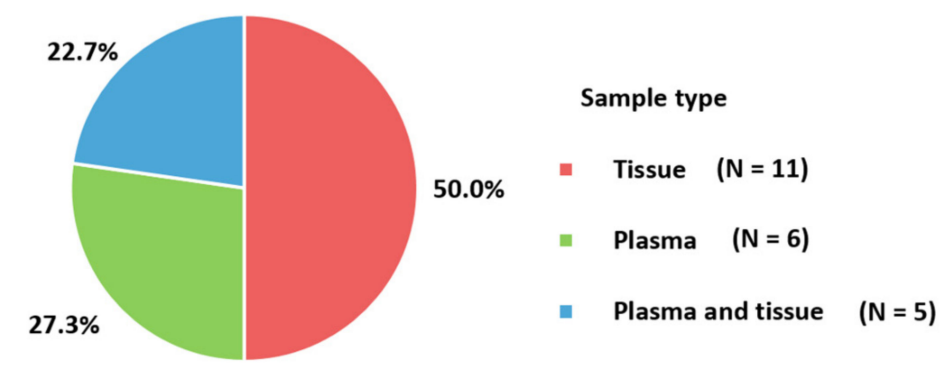

b

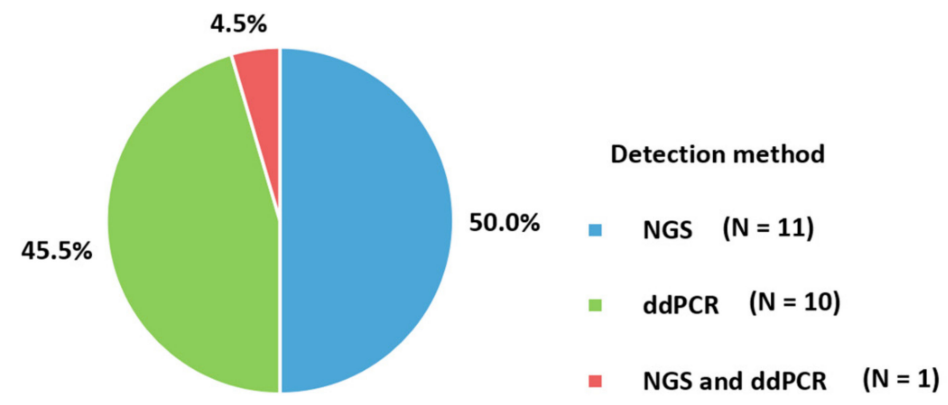

Figure 1. Applied laboratory assays for identifying ESR1 mutations. (a) Pie charts showing the sample types used; (b) Pie charts showing the use of molecular detection methods. NGS, next-generation sequencing; ddPCR, droplet digital polymerase chain reaction.

The differences in the sample types used for detecting ESR1 mutations according to previous publications are illustrated in Figure 2a. Plasma (46.2\%) became the most commonly used method in 2016-2019, in contrast to 2012-2015 (22.2\%). The easy accessibility, non-invasiveness, and usefulness of plasma samples with the increased use of ddPCR have influenced these trends.

a
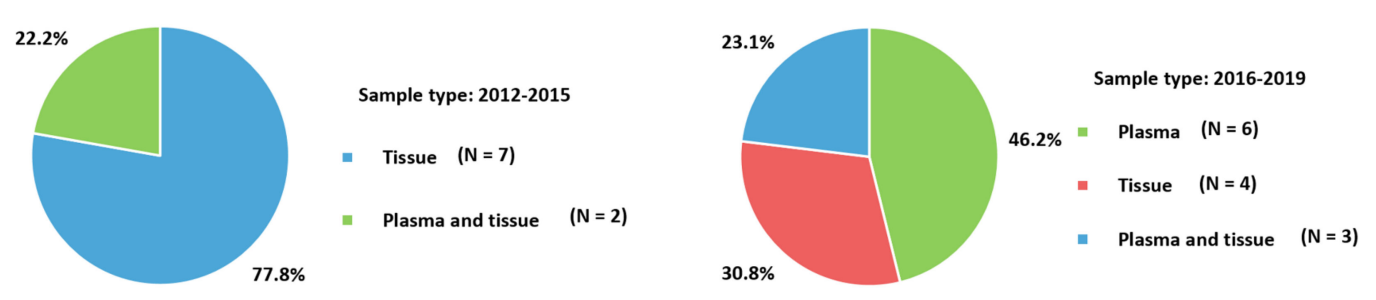

b

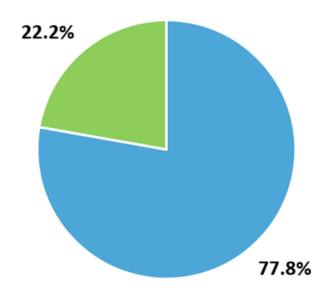

Detection method: 2012-2015

- NGS $(\mathrm{N}=7)$

ddPCR $(N=2)$

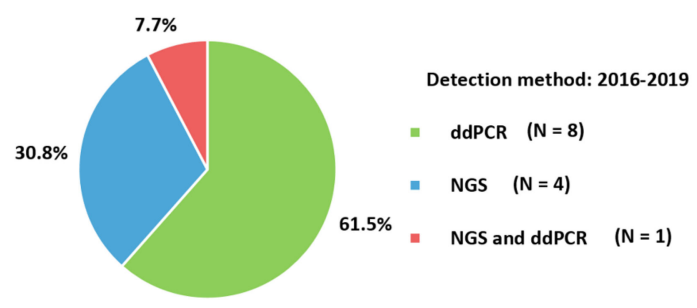

Figure 2. Changes in the application of molecular assays for detecting ESR1 mutations over time. (a) Pie charts showing the changes in the used sample types; (b) Pie charts showing the changes in the use of molecular detection assays. NGS, next-generation sequencing; ddPCR, droplet digital polymerase chain reaction. 


\section{Trends in Molecular Assays}

The molecular assays used and main characteristics observed in the studies of ESR1 mutations are presented in Table 1. The included studies were mainly based on three meta-analyses for ESR1 mutations in patients with breast cancer with resistance to endocrine therapy $[20,64,65]$. The search strategy terms for these systematic review and meta-analyses were as follows: ('estrogen receptor alpha' OR 'ESR1') AND ('breast neoplasms' OR 'breast cancer') AND ('neoplasm metastasis' OR 'metastasis' OR 'resistance'). Relevant articles with molecular assays for ESR1 mutations were also manually checked. A total of 22 studies were included to reflect assays currently used in clinical laboratories $[16,17,29,33-36,40,55,78-90]$. The most used molecular assay was NGS (50.0\%) followed by ddPCR (45.5\%) (Figure 1b). Targeted NGS gene panels are designed for a specific disease or a group of diseases, with the ability to maximize coverage, sensitivity, and specificity of the genes of interest. Therefore, targeted NGS gene panels often have higher diagnostic yields than exome sequencing or genome sequencing. One study reporting ESR1 mutations in bone metastases from breast cancer adopted NGS and ddPCR simultaneously [25]. NGS was performed for ESR1 coding regions, and all detected mutations were confirmed using pyrosequencing. The possible ESR1 amplification was also tested using ddPCR. Commercially available platforms for NGS were utilized (Illumina (San Diego, CA, USA) HiSeq 2000 or Hiseq 2500 (83.3\%) or Thermo Fisher Scientific Personal Genome Machine (PGM) instrument) (16.7\%)). For library preparation, hybridization capture with biotinylated RNA-based oligonucleotide probes from Agilent and barcoded sequence libraries provided by Illumina were frequently utilized. Paired-end sequencing was performed in most studies. For ddPCR, all included studies utilized platforms provided by Bio-Rad Laboratories except for two studies using the QuantStudio 3D Digital PCR System [91] from Thermo Fisher Scientific [35,78]. Generally, Sanger sequencing is used for confirming detected mutations in these molecular platforms. The most detected ESR1 mutation was D538G, followed by Y537 residues. Studies from Eastern countries are necessary because most studies have been conducted in Western countries.

The changes in molecular assays for ESR1 mutations in advanced breast cancer according to the epoch of examination are presented in Figure 2b. In 2016-2019, ddPCR (61.5\%) was more frequently used than NGS (30.8\%), and vice versa in 2012-2015. The advent of ddPCR focusing on ESR1 mutations with high sensitivity could influence changes in user preferences. 
Table 1. Molecular assays and main characteristics of the studies for advanced breast cancer with ESR1 mutations.

\begin{tabular}{|c|c|c|c|c|c|c|}
\hline First Author [Year] & Tumor Type $(n)$ & Sample Type & Detection Method & $\begin{array}{l}\text { Sequencing Equipment of Kit } \\
\text { (Company) }\end{array}$ & Most Frequent ESR1 & Study Country \\
\hline \multicolumn{7}{|l|}{ NGS based } \\
\hline Bartels et al., (2018), [78] & BC with bone metastases (231) & FFPE & NGS and ddPCR & $\begin{array}{l}\text { Ion PGM Hi-Q Kit v2 using } 318 \text { v2 } \\
\text { Chips and QuantStudio 3D Digital } \\
\text { PCR System (Thermo Fisher } \\
\text { Scientific, Germany) }\end{array}$ & D538G & Germany \\
\hline $\begin{array}{l}\text { Cancer Genome Atlas, } \\
(2012),[16]\end{array}$ & Luminal BC (169) & Tissue & $\begin{array}{l}\text { NGS and several } \\
\text { methods }\end{array}$ & Illumina (Illumina, USA) & NA & Multi-national \\
\hline Ellis et al., (2012), [17] & Luminal BC (46) & Snap-frozen tissue & NGS & Illumina (Illumina, USA) & NA & USA \\
\hline Jeselsohn et al., (2014), [40] & Metastatic BC (76) & FFPE & NGS & HiSeq2000 (Illumina, USA) & D538G and Y537N & USA and Spain \\
\hline Lefebvre et al., (2016), [29] & Metastatic BC (143) & $\begin{array}{c}\text { Fresh frozen tumor } \\
\text { biopsy }\end{array}$ & NGS & $\begin{array}{l}\text { Illumina HiSeq2500, HiSeq4000, or } \\
\text { NextSeq500 (Illumina, USA) }\end{array}$ & NA & France \\
\hline $\begin{array}{l}\text { Merenbakh-Lamin et al., } \\
\text { (2013), [55] }\end{array}$ & Metastatic BC (13) & FFPE & NGS & Illumina HiSeq2000 (Illumina, USA) & D538G & Israel \\
\hline Nik-Zainal et al., (2016) [83] & $\mathrm{BC}(560)$ & FFPE & NGS & $\begin{array}{l}\text { Illumina GAIIx, Hiseq } 2000 \text { or Hiseq } \\
2500 \text { (Illumina, USA) }\end{array}$ & NA & Multi-national \\
\hline Niu et al., (2015) [36] & Metastatic BC (222) & FFPE & NGS & $\begin{array}{l}\text { Illumina HiSeq2000 platform } \\
\text { (Illumina, USA) }\end{array}$ & Codon Y537 & USA \\
\hline Robinson et al., (2013) [33] & Metastatic BC (11) & Frozen needle biopsy & NGS & $\begin{array}{l}\text { Illumina HiSeq2000 platform } \\
\text { (Illumina, USA) }\end{array}$ & NA & USA \\
\hline Toy et al., (2013) [34] & $\begin{array}{l}\text { Advanced BC and Metastatic } \\
\text { BC (36) }\end{array}$ & $\begin{array}{l}\text { Fresh frozen tissue } \\
\text { and FFPE }\end{array}$ & NGS & Illumina Hiseq 2000 (Illumina, USA) & D538G & USA \\
\hline Toy et al., (2017) [87] & Metastatic BC (265) & FFPE & NGS & Illumina HiSeq 2500 (Illumina, USA) & D538G & USA \\
\hline Yanagawa et al., (2017) [89] & $\begin{array}{c}\text { Primary BC (16) and recurrent } \\
\text { BC (46) }\end{array}$ & FFPE and plasma & NGS & $\begin{array}{c}\text { Torrent PGM instrument (Thermo } \\
\text { Fisher Scientific, USA) }\end{array}$ & D538G & Japan \\
\hline
\end{tabular}


Table 1. Cont.

\begin{tabular}{|c|c|c|c|c|c|c|}
\hline First Author [Year] & Tumor Type (n) & Sample Type & Detection Method & $\begin{array}{l}\text { Sequencing Equipment of Kit } \\
\text { (Company) }\end{array}$ & Most Frequent ESR1 & Study Country \\
\hline \multicolumn{7}{|l|}{ ddPCR based } \\
\hline $\begin{array}{c}\text { Chandarlapaty et al., (2016) } \\
\text { [79] }\end{array}$ & $\begin{array}{l}\text { Metastatic BC (541) related to } \\
\text { BOLERO-2 clinical trial }\end{array}$ & Plasma in EDTA & Single ddPCR & $\begin{array}{l}\text { QX200 Droplet Digital PCR System } \\
\text { (Bio-Rad Laboratories, USA) }\end{array}$ & D538G & USA \\
\hline Chu et al., (2016) [80] & Metastatic BC (23) & $\begin{array}{l}\text { Plasma in Streck BCT } \\
\text { DNA tube or EDTA }\end{array}$ & ddPCR & $\begin{array}{l}\text { QX200 Droplet Digital PCR System } \\
\text { (Bio-Rad Laboratories, USA) }\end{array}$ & D538G & USA \\
\hline Clatot et al., (2016) [81] & BC with progression (144) & $\begin{array}{c}\text { Plasma in } \\
\text { heparinized tube }\end{array}$ & Single ddPCR & $\begin{array}{l}\text { QX200 Droplet Digital PCR System } \\
\text { (Bio-Rad Laboratories, USA) }\end{array}$ & D538G & France \\
\hline $\begin{array}{c}\text { Gyanchandani et al., (2017) } \\
\text { [90] }\end{array}$ & Relapsed or metastatic BC (16) & $\begin{array}{c}\text { Plasma in Streck } \\
\text { Cell-free DNA blood } \\
\text { tubes }\end{array}$ & ddPCR & $\begin{array}{l}\text { QX100 Droplet Digital PCR System } \\
\text { (Bio-Rad Laboratories, USA) }\end{array}$ & D538G & USA \\
\hline Fribbens et al., (2016) [82] & $\begin{array}{l}\text { BC with relapse or progression } \\
\text { (161) related to SoFEA and } \\
\text { PALOMA-3 clinical trials }\end{array}$ & Plasma in EDTA & $\begin{array}{l}\text { Multiplex and } \\
\text { uniplex ddPCR }\end{array}$ & $\begin{array}{l}\text { QX200 Droplet Digital PCR System } \\
\text { (Bio-Rad Laboratories, USA) }\end{array}$ & D538G & USA \\
\hline Schiavon et al., (2015] [84] & Advanced BC (171) & $\begin{array}{l}\text { Plasma in EDTA or } \\
\text { Streck Cell-Free DNA } \\
\text { BCT tube, and FFPE }\end{array}$ & Multiplex ddPCR & $\begin{array}{l}\text { QX200 Droplet Digital PCR System } \\
\text { (Bio-Rad, USA), Ion AmpliSeq Breast } \\
\text { Cancer Panel (Thermo Fisher } \\
\text { Scientific, USA), and PI chip using } \\
\text { the Ion PI OT2 200 Kit (Thermo } \\
\text { Fisher Scientific, USA) }\end{array}$ & D538G & United Kingdom \\
\hline Sefrioui et al., (2015) [35] & Metastatic BC (7) & $\begin{array}{l}\text { Frozen pleural biopsy, } \\
\text { FFPE for primary } \\
\text { tumor sample, and } \\
\text { plasma in heparinized } \\
\text { tube }\end{array}$ & ddPCR & $\begin{array}{l}\text { QuantStudio 3D Digital PCR System } \\
\text { (Thermo Fisher Scientific, USA) }\end{array}$ & NA & France \\
\hline Spoerke et al. (2016) [85] & $\begin{array}{l}\text { Metastatic BC (153) related to } \\
\text { FERGI clinical trial }\end{array}$ & Plasma and FFPE & ddPCR & $\begin{array}{l}\text { QX200 Droplet Digital PCR System } \\
\text { (Bio-Rad Laboratories, USA) }\end{array}$ & D538G & USA \\
\hline Takeshita et al., (2017) [86] & $\begin{array}{l}\text { Advanced BC (17) and } \\
\text { Metastatic BC (69) }\end{array}$ & Plasma in EDTA & Single ddPCR & $\begin{array}{l}\text { QX200 Droplet Digital PCR System } \\
\text { (Bio-Rad Laboratories, USA) }\end{array}$ & $\mathrm{Y} 537 \mathrm{~N}$ & Japan \\
\hline Wang et al., (2016) [88] & Primary or metastatic BC (29) & $\begin{array}{l}\text { Frozen tissue and } \\
\text { plasma in Streck tubes }\end{array}$ & ddPCR & $\begin{array}{l}\text { QX100 Droplet Digital PCR System } \\
\text { (Bio-Rad Laboratories, USA) }\end{array}$ & D538G & USA \\
\hline
\end{tabular}

BC, breast cancer; FFPE, formalin-fixed paraffin-embedded; NGS, next-generation sequencing; ddPCR, droplet digital polymerase chain reaction. 


\section{Molecular Assays}

\subsection{Next-Generation Sequencing}

NGS has offered a quantum leap in the field of molecular assays. The NGS technique provides significant improvements in sequencing speed and throughput because of the automated streamlined workflow. The overall workflow consists of template preparation such as nucleic acid extraction, library preparation, sequencing, bioinformatics, and data interpretation. Several manufacturer-specific platforms, such as the Illumina HiSeq and Ion Torrent PGM systems have been developed for identifying ESR1 mutations.

\subsubsection{Library Preparation}

The preparation of an NGS library starts with the fragmentation of nucleic acids. Physical techniques such as acoustic shearing, sonication, and hydrodynamic shear or enzymatic methods, including digestion by deoxyribonuclease I and Fragmentase, have been used for fragmentation [92,93]. Sequence adaptors, which create known starts and ends, are connected to fragments for enrichment. Fragments are selected according to the desired library size. When DNA libraries contain shorter fragments of similar sizes, short-read sequencers adopted most commonly in the included studies yielded the best results. Illumina fragments (up to 1500 bases) are longer than Ion Torrent PGM fragments (up to 400 bases) [92,94]. The shorter fragments are feasible for targeted and exome sequencing rather than whole-genome sequencing, as most of the human exons are less than 200 base pairs in length [95]. The following enrichment step increased the amount of target DNA for sequencing. Capture hybridization-based sequencing and amplicon-based sequencing exist for targeted strategies [96,97]. The former method utilizes biotinylated oligonucleotide probes, and fragmented materials are hybridized physically to DNA fragments complementary to the targeted regions. The widely used SureSelect kit (Agilent) for library preparation in the included studies is based on this hybrid capture methodology [94]. For amplicon-based methods, synthetic oligonucleotides with a sequence complementary to the flanking region of the target DNA were utilized. The representative commercially available kit is Ion AmpliSeq from Thermo Fisher Scientific. The limitations of this amplicon-based preparation originate from PCR amplifications, including primer competition, duplicates, and non-uniform amplification of target regions because of the variation in GC content. Hybrid capture techniques have advantages concerning uniform coverage and depth over amplicon-based methods. However, hybrid capture techniques require more time and higher costs than amplicon strategies [96,97]. To overcome these limitations, barcoded sequence libraries using unique molecular identifiers ligated to DNA fragments were developed [98] for sequencing ESR1 mutations using TruSeq of Illumina [34]. PCR duplicates were detected using non-unique fragments combined with unique molecular identifiers [98,99].

\subsubsection{Sequencing Platforms}

Illumina

Illumina platforms are the most widely used in our included studies for detecting ESR1 mutations. Illumina developed a bridge PCR strategy for clonal amplification and sequencing through a reversible terminator. Fragmented DNA is attached to fixed adapters on the solid surface of the flow cell. Bridge amplification forms double-strand bridges followed by denaturation to generate single-stranded templates. After repeating this process, several millions of dense clusters containing clonal fragments are generated in each channel of the flow cell. A reversible terminator, a single labeled complementary deoxynucleotide triphosphate, retains a cleavable fluorescent dye. When reversible terminators are added to the template during synthesis, fluorescent signals are captured and recorded during each cycle [100]. This methodology substantially reduces the homopolymer sequencing error because the addition of a single base at a time is required [100,101]. However, some fluorescent dyes may have a 
partial overlap between the emission spectra of the fluorophores during the process. Moreover, they may lose activity, limiting the base calling on this Illumina platform [102,103].

The most used Illumina sequencers in the included studies for ESR1 mutation were HiSeq2000 and Hiseq 2500, launched in 2012 [104] (Table 1). Both platforms belong to second-generation sequencing technologies and utilize four-channel sequencing using a synthesis system in which each fluorescently labeled base is detected using individual images. Their common read lengths were $100 \times 100$ base pairs. The maximal output and run time were $600 \mathrm{~GB}$ and $11 \mathrm{~d}$, respectively. The difference between HiSeq2000 and Hiseq 2500 is the fast run mode adopted in the Hiseq 2500 system. When the fast run mode is operated, the read length becomes $150 \times 150$ base pairs. Additionally, the run time can be reduced to $27 \mathrm{~h}$ in the fast run mode [105]. NextSeq 500 and HiSeq 4000 systems, launched in 2014 and 2015, respectively, were also utilized for detecting ESR1 mutations [29]. NextSeq 500 utilizes two-channel sequencing using the synthesis system, which requires only two images to measure all four base calls. This new methodology decreases the sequencing cost and time by reducing the number of cycles and imaging capture time. HiSeq 4000 systems adopted billions of pre-formatted nanowell grids at fixed locations, leading to a much higher data output than previous platforms using normal flow cells [101]. Altogether, Illumina systems have been used most commonly in laboratory settings for detecting ESR1 mutations because of their high throughput, accuracy, and relatively low cost.

Ion Torrent

Ion Torrent employs semiconductor sequencing utilizing hydrogen ion detection technology. The fragmented molecules are attached to the beads with specific adapter sequences. Amplification using emulsion PCR generates beads with clonally amplified target DNA [106]. Each bead is then loaded into the microwells on the semiconductor sensor array chip. When nucleotides are incorporated into growing strands, protons are released, causing $\mathrm{pH}$ changes, and the ion sensor on the complementary metal-oxide-semiconductor chip detects these signals $[107,108]$.

The first Ion Torrent PGM sequencer, launched in 2010, was most frequently used in laboratories for detecting ESR1 mutations (Table 1) [78,89]. The PGM has a read length of approximately 400 base pairs ( $200 \times 200$ base pairs for paired-end sequencing). Maximal output is up to $1 \mathrm{~GB}$ per run, and the run time is fast $(2-7 \mathrm{~h})[32,33]$. The Ion Torrent platform covers long reads and is more direct, more rapid, and less expensive than Illumina, which relies on laser scanners. However, these sequencers yield relatively low output and are vulnerable to insertion/deletion (indel) errors associated with homopolymeric stretches and repeats [109]. The observed raw error rate of Ion Torrent PGM $(1.71 \%)$ was higher than that of Illumina HiSeq 2000 (0.26\%) [110]. Advanced models of second-generation sequencing platforms with higher throughput, easier preparation, and shorter run time have been developed and will be utilized in future studies for identifying ESR1 mutations.

\subsubsection{Bioinformatics}

The huge amount of NGS data generated using sequencing platforms requires computational and bioinformatics skills for management, analysis, and interpretation. Bioinformatics has been developed and improved based on algorithms, software applications, and increased computational capacities of hardware. Basic procedures for analyses are common; however, this study focuses on Illumina and Ion Torrent, the two major second-generation platforms, and each system has its own particularities and specificities.

First, the detection and analysis of raw data, base calling, and scoring base quality (Phred score) are required. Typical outputs from this step are the fastq file of Illumina and the unmapped binary alignment map file from Ion Torrent. Fastq files containing all the raw sequencing reads, file names, and quality values are essential for the first quality control step [111]. Several bioinformatics tools have been developed for evaluating the quality of raw data, such as the NGS QC toolkit [112], QC-Chain [113], and FastQC [111]. FastQC, one of the most popular tools, provides a report presenting well-structured and graphically illustrated information about quality. Additional trimming is conducted at the ends of 
each read to eliminate adapter sequences. Among some trimming tools for Illumina data, appropriate tools are selected according to the dataset, downstream analysis, and parameters used [114]. For Ion Torrent, sequencing and data management are processed in the Torrent Suite software. After trimming, the removal of remaining library adapter sequences from the ends of the reads, demultiplexing was performed. This step is required to prevent interfering with mapping and assembly owing to residual adaptor sequences in the reads [114].

The next step is read alignment against the reference human genome (typically hg19 or hg38), which is preferred in clinical settings rather than de novo assembly for mapping sequence reads [115]. Burrows-Wheeler Aligners and Bowtie are the most widely used alignment software programs for Illumina data, whereas the Torrent Mapping Alignment Program is recommended for Ion Torrent $[116,117]$. As output, a binary alignment/map (BAM) containing a text file format and a sequence alignment/map (SAM) format having binary versions can be obtained after analyses [118]. The Interactive Genome Viewer [119] is available for checking the alignments. Post-alignment processing for reducing the base call and alignment artifacts is necessary for improving the variant call accuracy and quality of the downstream process [120]. SAMtools [118], Genome Analysis Toolkit (GATK) [121], and Picard [94] are useful tools for post-alignment processing. The variant calling step is processed for identifying variants using tools such as SAMtools, GATK, and Freebayes for Illumina data [122] and Torrent Variant Caller for Ion Torrent. A variant calling format (VCF) file can be generated via these tools, mostly from the SAM/BAM format as the input [123]. The VCF file contains meta-information lines, a header line, and data lines presenting information about the chromosomal position, reference base, and identified alternative base. The last analysis starts with variant annotation, which inserts a further layer of information into all the variants identified in previous variant calling steps to predict their functional impacts. Several annotation tools based on functionality include SIFT [124], PolyPhen-2 [125], CADD [126], and Condel [127], which calculate the consequence scores for each variant based on the degree of conservation of amino acid residues, evolutionary conservation, sequence homology, protein structure, or statistical prediction derived from known mutations. For the clinical associations, ClinVar and HGMD, disease variants databases, can be utilized. After annotation, steps for making clinical sense and identifying disease-causing variants via some filtering strategies are required.

After variant annotation, steps for variant filtering, prioritization, and data visualization should be followed. A combination of several software programs is required to conduct these analytical steps. The total number of independent reads and the percentage of reads presenting the variant and the homopolymer length (especially for Ion Torrent) could be applied as quality parameters for decreasing variant call errors and the number of false-positive calls. The user should determine the threshold, such as 10 independent reads, based on the observed data for filtering sequencing bias or low coverage. Additionally, minor allele frequency [128] and population databases, such as the 1000 Genomes Project [129], Exome Aggregation Consortium [130], and Genome Aggregation Database can be powerful tools for filtering. The representative American College of Medical Genetics and Genomics and the European Society of Human Genetics guidelines provide standards and guidelines for the evaluation and interpretation of genomic variations from NGS [131].

\subsubsection{NGS strategies}

\section{Targeted Panel Sequencing}

Targeted panels designed for specific genes can maximize coverage, sensitivity, and specificity for the included genes. Therefore, targeted panel sequencing provides a higher diagnostic yield than whole exome sequencing or whole-genome sequencing. The cost of targeted panels is usually lower than that of whole exome sequencing. Niu et al. [36] used targeted NGS platforms for 315 cancer-related genes and 28 genes commonly rearranged in cancer. ESR1 mutations are one of the genomic alterations reported using this targeted panel. 
Whole Exome Sequencing

Whole exome sequencing analyzes all exons, and clinical exome sequencing targets approximately 22,000 protein-coding genes. These sequencing strategies increase the chances of detecting pathogenic variants. Patients with negative results in targeted panel sequencing or complex phenotypes are usually indicated for exome sequencing [104]. Among the included studies, a study investigating the association between ESR1 mutations and efficacy of ER antagonists [87] utilized a commercially available MSK-IMPACT assay, a targeted sequencing assay covering all protein-coding exons and introns of $410 \mathrm{key}$ oncogenes. Other studies evaluating the mutational profile of metastatic breast cancers [29] and comprehensive molecular portraits of breast malignancies [16] adopted whole exome sequencing using Illumina platforms.

\section{Whole Genome Sequencing}

Whole genome sequencing is a comprehensive technique for analyzing the entire genome. It can detect variants missed using targeted panel sequencing or whole exome sequencing, providing increased diagnostic yield [104]. In terms of costs, a single test ranged from 555-5169 USD for exome sequencing and 1906-24,810 USD for whole genome sequencing based on a recently published meta-analysis on the cost-effectiveness of different sequencing platforms [132]. Several studies on ESR1 mutations treated with endocrine therapy utilized whole exome sequencing using Illumina platforms $[16,17,36]$.

\subsection{Droplet Digital PCR}

After second-generation PCR, such as real-time quantitative PCR quantifying the target molecules with standard curves, the revolutionary ddPCR as the third-generation PCR was developed and commercialized in 2011. This methodology allows absolute quantification via partitioning of the reaction [133]. Therefore, it is applied for the detection of ESR1 mutations because of its high sensitivity and accuracy.

Briefly, molecules are separated randomly into numerous small-volume compartments, such as water-oil emulsion droplets (emulsion-based digital PCR) or a chip with microchannels (microfluidics-based digital PCR) automatically. The distribution of target sequences in the compartments can be calculated using Poisson statistics. Each compartment functions as an individual PCR micro-reactor. The amplified target sequences are identified using fluorescence, and the initial copy number and concentration of the target molecule can be obtained. This method provides a template to approximately 20,000 droplets before amplification, showing high sensitivity for finding mutations in DNA with a detection limitation of $0.001 \%$ [134]. The numerous micro-compartments contribute to the increase in the tolerance of the PCR system to inhibitors. Based on this high sensitivity compared to $1 \%$ of traditional PCR, it has been applied for the detection of circulating tumor DNA. Furthermore, ddPCR has been technologically modified into a commercial tool that is more operable and compatible. Its two-dimensional data are highly readable [135]. According to the representative scatter plot of ddPCR results of the Bio-Rad QX200 ddPCR system, which was mostly utilized in our studies for identifying ESR1 mutations, the mutant allele appeared to be blue and the wild-type reference allele was shown in green using fluorescent probes. Double-positive droplets harboring both types of molecules are presented in orange, whereas double-negative droplets with no amplification are presented in gray. Moreover, ddPCR generates reliable results with small amount of samples because of the elimination of error from pre-amplification. Therefore, it enables the utilization of samples with degraded nucleic acids and samples that are difficult to obtain [136]. Furthermore, ddPCR provides high-repeatability results based on its independence of amplification efficiency. It defines the amplification results as positive and negative and quantifies the results with counts assisted using Poisson statistics. The drawbacks of ddPCR include a narrow dynamic range and a relatively higher cost than real-time quantitative PCR. However, the cost of ddPCR is lower than that of NGS technology. 
Based on our included studies, ddPCR technologies are increasingly being used for the detection of ESR1 mutations in advanced breast cancers owing to the enhanced sensitivity of ddPCR, which enables more accurate positive detection of ESR1 mutations in plasma samples. The Bio-Rad QX200 and QX 100 ddPCR systems are the most widely utilized. In the BOLERO-2 clinical trial, allele-specific assays for ESR1 D538G and Y537S mutations were designed and optimized for quantification using the QX200 ddPCR system. The extracted cfDNA was analyzed for the presence of ESR1 mutations using single ddPCR assays [79]. Fribbens et al. [82] used both multiplex and single ddPCR assays to identify the seven most common ESR1 mutations from the SoFEA and PALOMA-3 samples. If at least two ESR1 mutant droplets are observed, a multiplex assay is determined to be positive. The results from the multiplex ddPCR format are further characterized using single ddPCR assays. Schiavon et al. [84] also developed multiplex ddPCR assays by varying the concentration of fluorescent probes for distinguishing mutations based on fluorescence intensity. A study of ESR1 mutations in patients with ER-positive metastatic breast cancer treated with fulvestrant [85] designed ddPCR probe assays for 10 ESR1 mutations in samples from the FERGI clinical trial. Wang et al. [88] assessed six ESR1 mutations (K303R, S463P, Y537C, Y537N, Y537S, and D538G) using ddPCR (QX100 Droplet Digital PCR System) with a lower limit of detection of $0.05-0.16 \%$. Studies on ESR1 mutations in circulating plasma tumor DNA $[80,86,90]$ and for evaluating the prognostic and predictive values of ESR1 circulating mutations [81] employed Bio-Rad ddPCR systems. Two studies employed the QuantStudio 3D Digital PCR System from Thermo Fisher Scientific [35,78]. Bartels et al. [78] performed ddPCR using chip-based nanofluidics to assess possible ESR1 gene amplification and for confirming NGS variant detection. The application of ddPCR to circulating tumor DNA for detecting ESR1 mutations and monitoring treatment response or progression is still being investigated. Several clinical trials, such as BOLERO-2 [79], SoFEA, PALOMA-3 [82], and FERGI [85], also used ddPCR, demonstrating a need for the routine use of targeted sequencing of liquid biopsies.

\subsection{Other Methods}

\subsubsection{Sanger Sequencing}

The first-generation platform, Sanger sequencing developed by Fred Sanger in 1977 [137] was the primary sequencing technology for the subsequent two and a half decades. It has long been considered the reference standard for nucleic acid sequencing. Sanger sequencing generates relatively long (500-1000 base pairs), high-quality DNA sequences [138]. Sanger sequencing and ER-specific exon PCR were utilized to identify an ESR1 mutation, Y537N, from a metastatic ER-positive tumor biopsy in 1997 [52]. Recently, Sanger sequencing has been used to confirm mutations identified using NGS or ddPCR technology. DNA from a cell line with a D538G knock-in mutation and that from a liver biopsy with an ESR1 mutation at Y537S showing high allele frequencies were confirmed using Sanger sequencing [88]. In another study, mutations found in recurrent breast tumors with more than $10 \%$ mutant allele frequency via NGS were confirmed using the Sanger method with a commercially available ABI PRISM 310 Genetic Analyzer (Applied Biosystems, Foster, CA, USA) [89]. Sanger sequencing has been utilized mainly for confirmation because it requires much more time and cost than NGS technology.

\subsubsection{Pyrosequencing}

The advent of pyrosequencing technology by Roche 454 sequencing (Roche, Switzerland) in 2005 began the NGS revolution [139]. It was the first commercially available massive parallel sequencing platform that generates thousands to millions of short sequencing reads (140-200 bases for paired end reads) in a single machine run without cloning [105]. Pyrosequencing methodology captures pyrophosphate release and uses it as an indicator of specific base addition. After binding fragmented DNA to beads through ligated adaptors, emulsion PCR within an emulsion droplet results in fragment amplification [106]. The beads harboring multiple copies of the same DNA template are loaded into 
PicoTiterPlate wells. Each nucleotide is sequentially flowed into the wells. During DNA synthesis, a nucleotide is incorporated, and the pyrophosphate released is converted to ATP. Luciferase converts luciferin to oxyluciferin to generate light in the presence of ATP. The signal is then detected and captured using a coupled-charge device camera $[139,140]$. Sequencing accuracy relies on the reading of the light signals. A misread or missing signal related to homopolymer sequencing leads to base errors, insertions, or deletions. Roche 454 was replaced with emerging NGS platforms, such as the Ion Torrent (Thermo Fisher) and Illumina systems, in 2016, owing to its higher cost. Among our included studies, pyrosequencing was performed for sequencing ESR1 exon 5. In addition, it was also used to confirm all mutations in ESR1 identified using the Ion Torrent NGS platform [78].

\subsubsection{Real-Time PCR}

The real-time PCR technique, a prior form of ddPCR, has been used in several genetic platforms for patients with breast cancer. This method requires the amplification of specific DNA targets using PCR and monitoring of the amplification reaction using fluorescence. It is routinely used for the analysis of gene expression and quantification [141]. Reverse transcription of RNA into cDNA is frequently coupled with this type of PCR. Multiplex PCR targeting various molecules based on real-time PCR is also performed using commercial products. In the oncology field, it is one of the methods for measuring minimal residual disease in patients with breast cancer [142]. Jeselsohn et al. [40] adopted this method for measuring mRNA levels after synthesizing cDNA using a reverse transcription kit. Although real-time PCR involves relatively shorter run and hands-on times and is more sensitive and provides more reliable results than traditional PCR, [143] one should consider the possible disadvantages, such as false-positive results owing to non-specific amplification, contamination, and false-negative results owing to low gene expression.

\subsubsection{Microarray}

The microarray technique, which is a collection of microscopic DNA or RNA spots attached to a solid surface, has been used for a small number of breast tumor tissues. Microarrays are utilized as a high-throughput method for measuring the expression of a large number of genes, including the ESR1 gene [144]. In breast cancer, it is used to quantify relative transcript abundance. In addition, MammaPrint, a genetic platform, is a microarray-based assay for determining prognosis in breast cancer using the expression levels of 70 genes to assess the risk of recurrence [145]. Among the included studies, Ellis et al. [17] validated all putative somatic mutations via targeted custom capture arrays. In another study, Agilent mRNA expression microarrays and Illumina Affymetrix 6.0 single-nucleotide polymorphism arrays containing more than 906,600 probes were adopted for the comprehensive molecular portraits of breast malignancies [16].

\subsubsection{Methylation}

DNA methylation, a reversible epigenetic change, plays an important role in the carcinogenesis, progression, and prognosis of various malignancies. Genes with aberrant promoter methylation are known to be closely associated with breast cancer development and progression [146]. Methylation mediates the silencing of genes and drives speculation regarding the role of molecular crosstalk between genes or genetic pathways. According to a recently published meta-analysis [147], ESR1 promoter methylation is related to a worse overall survival of patients with breast cancer. This meta-analysis included three studies on ESR1 methylation. A study on DNA methylation profiles of breast cancer was performed using the MethyLight assay [148] for DNA methylation analysis. After sodium bisulfite-converted genomic DNA amplification, fluorescence was identified using a laser detector. The percentage of fully methylated molecules at a specific locus was calculated [149]. In the remaining two studies $[150,151]$, methylation-specific PCRs were performed to analyze the methylation status of methylated genes in breast cancer tissues. Two sets of primers were designed for the targeted gene. One was specific for DNA methylation at the promoter region and the other was specific for 
unmethylated DNA. After amplification, each PCR product was identified. Additionally, Illumina Infinium DNA methylation arrays and the main NGS platform were used for the molecular profiles of breast malignancies [16].

\section{Future of Molecular Assays}

Advanced types of NGS techniques and modified forms of ddPCR exhibiting micro-sized instruments, ultra-sensitive and specific detectors, faster turnaround times, and lower costs will be developed in the future for detecting ESR1 mutations more efficiently. Although second-generation NGS technologies have substantially impacted this field, short sequence reads resulting in sequence gaps, alignment issues related to repetitive regions or pseudogenes, and PCR artifacts remain to be addressed [94]. Third-generation sequencers based on single-molecule sequencing techniques have been developed to overcome these limitations [152,153]. The representative commercial platforms are single-molecule real-time Sequel systems from Pacific Biosciences (Menlo Park, CA, USA) and MinION from Oxford Nanopore Technologies (Oxford, UK) [154]. PacBio platforms (Pacific Biosciences) allow much longer sequencing reads (average, 10-15 kb), shorter sample preparation (4-6 h), shorter sequencing run time (within a day/run), and reduced GC bias and sequencing errors derived from PCR amplification. However, it has a relatively high error rate (10-15\%) owing to indels caused by miscalls. The nanopore sequencing platform relies on electrical changes as each nucleotide passes through the nanopore [155]. Nanopore technology exhibits short turnaround time and no GC bias and is independent of amplification steps requiring fluorescence labeling and DNA polymerase. The most apparent drawback of this technology is the high sequencing error rate of $14 \%$, which stems from errors from indels. Altogether, the third-generation platforms provide longer sequence reads, which can contribute to sequencing of extended repetitive elements and characterizing pathogenic structural variations in advanced breast tumors. The disadvantages of this technology might be complemented by combining second- and third-generation NGS methodologies [156].

The BEAMing method is a modified type of digital PCR that is based on beads, emulsion, amplification, and magnetics. Water droplets in an oil emulsion serve as reaction vessels and contain primers, a mixture of template, PCR reagents, and magnetic beads. Fluorescently labeled dideoxynucleotide terminators are utilized to differentiate droplets containing sequences of interest and are analyzed via flow cytometry [157]. BEAMing exhibited a highly sensitive detection rate of $0.02 \%$ mutant allele frequency and a specificity of $100 \%$, with a small amount of required DNA input and a higher than 90\% concordance rate between tissue and circulating tumor DNA from the breast [157]. Moreover, good agreement between BEAMing and ddPCR and applying BEAMing to a large-scale clinical trial could be evidence of sufficient reproducibility for clinical use [158,159]. Despite its high performance, the complicated workflow and high cost should be overcome for routine clinical work. Additionally, Lupini et al. [160] developed enhanced-ice-COLD-PCR with high sensitivity and demonstrated the utility of this approach with respect to simplification and improvement for detecting ESR1 mutations. Furthermore, a commercially available Guardant360 assay based on an NGS assay utilizing circulating tumor DNA to identify genomic alterations among 54-70 cancer-related genes, including 18 copy number variants and six gene fusions, was also adopted for personalized cancer treatment for breast tumors [161].

Genetic profiling of putative genetic factors associated with resistance to endocrine therapy using molecular tools such as NGS and digital PCR might improve patient prognosis and increase accuracy in predicting responses to therapeutic interventions. Furthermore, rapid and accurate detection of ESR1 alterations based on the advent of newly developed methods for differentiating subtypes and emerging variants resistant to currently used therapies will greatly benefit patients with advanced breast cancers. Analytical and clinical validation should be conducted before using new techniques in clinical laboratories. 


\section{Conclusions}

In summary, applied molecular methodologies for identifying ESR1 mutations, one of the major causes of resistance to endocrine therapy in patients with advanced breast cancer, were reviewed. The main methods used for detecting ESR1 mutations in laboratories are NGS-based assays, including Illumina and Ion Torrent platforms. This is followed by ddPCR, including single and multiplex assays, accounting for approximately half of the molecular methods. Regarding sample types used for molecular assays, tissues such as FFPE and fresh frozen samples were once the major resources for detecting ESR1 mutations. However, comparison of the sample types using a wide range of available data showed that plasma obtained from EDTA, Streck Cell-free DNA blood, and heparinized tubes have become the more appropriate specimens according to the changes in the adopted molecular assays. The predominant method for detecting ESR1 mutations involves ddPCR in the recent epoch. Although NGS-based assays are still in use because of their wide dynamic range for detecting mutation alterations, ddPCR offers higher sensitivity, economic feasibility, and highly readable and repeatable results. Moreover, easier accessibility because of non-invasiveness and minimal sample volumes have influenced the preference for ddPCR. The advent of ddPCR facilitates routine investigations of ESR1 mutations as a potential monitoring biomarker for patients with breast cancer treated with endocrine therapy. When using these molecular assays, it is important to have a comprehensive understanding of the associated principles, advantages, disadvantages, and precautions for data interpretation (Table 2). 
Table 2. Summary of commonly used molecular assays for the detection of ESR1 mutations.

\begin{tabular}{|c|c|c|c|}
\hline Detection Method & Principle & Advantage & Limitation \\
\hline NGS platforms & $\begin{array}{l}\text { - Massive parallel sequencing (mostly } \\
\text { second generation) }\end{array}$ & $\begin{array}{l}\text { - Higher throughput and faster time than } \\
\text { Sanger sequencing } \\
\text { - Detecting more dynamic range of genetic } \\
\text { alterations than ddPCR }\end{array}$ & $\begin{array}{l}\text { - } \quad \text { Time-consuming for data analysis } \\
\text { - Necessity of special knowledge } \\
\text { for bioinformatics }\end{array}$ \\
\hline Illumina & $\begin{array}{l}\text { - Amplification: Bridge PCR } \\
\text { - Sequencing: Synthesis using fluorescently } \\
\text { labelled reversible terminator } \\
\text { Detection: bases from individual images } \\
\text { using camera }\end{array}$ & $\begin{array}{l}\text { Higher throughput and accuracy than Ion } \\
\text { Torrent because of the addition of a single base at } \\
\text { a time reducing the homopolymer } \\
\text { sequencing error }\end{array}$ & $\begin{array}{l}\text { - Partial overlap between emission spectra o } \\
\text { the fluorophores and losing activity of } \\
\text { fluorescent dyes limiting the base calling }\end{array}$ \\
\hline Ion Torrent & $\begin{array}{l}\text { - } \quad \text { Amplification: Emulsion PCR } \\
\text { - } \quad \text { utilizing hydrogen ion detection } \\
\text { Detection: signals using ion sensor on the } \\
\text { complementary } \\
\text { metal-oxide-semiconductor chip }\end{array}$ & $\begin{array}{l}\text { - Longer reads and easier preparation and more } \\
\text { direct, rapid, and less expensive than Illumina } \\
\text { relying on laser scanners }\end{array}$ & $\begin{array}{l}\text { Relatively low output and higher raw error } \\
\text { rate due to vulnerability to } \\
\text { insertions/deletions (indels) errors } \\
\text { associated with homopolymeric stretches } \\
\text { and repeats when compared to Illumina }\end{array}$ \\
\hline ddPCR & $\begin{array}{l}\text { Partitioning the reaction through water-oil } \\
\text { emulsion droplets (emulsion-based digital } \\
\text { PCR) or a chip with micro-channels } \\
\text { (microfluidics-based digital PCR) } \\
\text { - Identified of target sequences using } \\
\text { fluorescence and subsequent calculation } \\
\text { the initial copy number and concentration } \\
\text { of target molecules }\end{array}$ & $\begin{array}{l}\text { - Application to the detection of circulating tumor } \\
\text { DNA based on high sensitivity with a detection } \\
\text { limitation of } 0.001 \% \\
\text { - } \quad \text { Absolute quantification via micro-partitioning } \\
\text { Increase of the tolerance of PCR system to } \\
\text { inhibitors because of the } \\
\text { numerous micro-compartments } \\
\text { - } \quad \text { Highly readable two-dimensional data } \\
\text { Reliable results with small amount of samples } \\
\text { because of the elimination error } \\
\text { from pre-amplification } \\
\text { - High repeatability results based on its } \\
\text { independence on amplification efficiency } \\
\text { - Lower cost compared to NGS platforms }\end{array}$ & $\begin{array}{l}\text { - Narrow dynamic range for genetic } \\
\text { alterations compared to NGS technology } \\
\text { - } \quad \text { Relatively higher cost than real-time } \\
\text { quantitative PCR }\end{array}$ \\
\hline
\end{tabular}

NGS, next-generation sequencing; ddPCR, droplet digital polymerase chain reaction. 
Author Contributions: Conceptualization, N.L. and S.J.; methodology, K.J.; software, N.L.; validation, M.-J.P. and W.S.; formal analysis, N.L. and S.J.; investigation, N.L.; resources, K.J. and S.J.; data curation, W.S. and S.J.; writing — original draft preparation, N.L.; writing—review and editing, M.-J.P. and S.J.; visualization, K.J.; supervision, M.-J.P. and W.S.; project administration, S.J.; funding acquisition, S.J. All authors have read and agreed to the published version of the manuscript.

Funding: This research was funded by National Research Foundation of Korea (NRF) grant, grant number [NRF-2017R1C1B2004597] and Hallym University Research Fund 2020 (HURF-2020-H20200643). The APC was funded by NRF.

Acknowledgments: The authors would like to thank Hyun Jung Kim (Korea University College of Medicine) and the Biomedical Research Institute (Pusan National University Hospital) for providing technical support and statistical consultation.

Conflicts of Interest: The authors declare no conflict of interest. The funders had no role in the design of the study; in the collection, analyses, or interpretation of data; in the writing of the manuscript, or in the decision to publish the results.

$\begin{array}{ll}\text { Abbreviations } \\ \text { BAM } & \text { Binary Alignment/map } \\ \text { CCDC170 } & \text { Coiled-Coil Domain Containing 170 } \\ \text { cfDNA } & \text { Cell-Free DNA } \\ \text { ddPCR } & \text { Droplet Digital Polymerase Chain Reaction } \\ \text { EDTA } & \text { Ethylenediaminetetraacetic Acid } \\ \text { EGFR } & \text { Epidermal Growth Factor Receptor } \\ \text { ER } & \text { Estrogen Receptor } \\ \text { FFPE } & \text { Formalin-Fixed Paraffin-Embedded } \\ \text { GATK } & \text { Genome Analysis Toolkit } \\ \text { HER2 } & \text { Human Epidermal Growth Factor Receptor2 } \\ \text { LBD } & \text { Ligand-Binding Domain } \\ \text { NGS } & \text { Next-Generation Sequencing } \\ \text { PGM } & \text { Personal Genome Machine } \\ \text { PR } & \text { Progesterone Receptor } \\ \text { SAM } & \text { Sequence Alignment/map } \\ \text { SMRT } & \text { Single Molecule Real-Time } \\ \text { VCF } & \text { Variant Calling Format }\end{array}$

\section{References}

1. Global Cancer Observatory: Cancer Tomorrow. Available online: https:/gco.iarc.fr/tomorrow/graphicisotype (accessed on 10 November 2020).

2. Bray, F.; Ferlay, J.; Soerjomataram, I.; Siegel, R.L.; Torre, L.A.; Jemal, A. Global cancer statistics 2018: GLOBOCAN estimates of incidence and mortality worldwide for 36 cancers in 185 countries. CA Cancer J. Clin. 2018, 68, 394-424. [CrossRef] [PubMed]

3. Huang, Z.; Wen, W.; Zheng, Y.; Gao, Y.T.; Wu, C.; Bao, P.; Wang, C.; Gu, K.; Peng, P.; Gong, Y.; et al. Breast cancer incidence and mortality: Trends over 40 years among women in Shanghai, China. Ann. Oncol. 2016, 27, 1129-1134. [CrossRef] [PubMed]

4. Torre, L.A.; Bray, F.; Siegel, R.L.; Ferlay, J.; Lortet-Tieulent, J.; Jemal, A. Global cancer statistics, 2012. CA Cancer J. Clin. 2015, 65, 87-108. [CrossRef] [PubMed]

5. Romieu, I.; Biessy, C.; Carayol, M.; His, M.; Torres-Mejia, G.; Angeles-Llerenas, A.; Sanchez, G.I.; Jaramillo, R.; Navarro, E.; Porras, C.; et al. Reproductive factors and molecular subtypes of breast cancer among premenopausal women in Latin America: The PRECAMA study. Sci. Rep. 2018, 8, 13109. [CrossRef]

6. Yersal, O.; Barutca, S. Biological subtypes of breast cancer: Prognostic and therapeutic implications. World J. Clin. Oncol. 2014, 5, 412-424. [CrossRef]

7. Hu, Z.; Fan, C.; Oh, D.S.; Marron, J.S.; He, X.; Qaqish, B.F.; Livasy, C.; Carey, L.A.; Reynolds, E.; Dressler, L.; et al. The molecular portraits of breast tumors are conserved across microarray platforms. BMC Genom. 2006, 7,96. [CrossRef] 
8. Sorlie, T.; Perou, C.M.; Tibshirani, R.; Aas, T.; Geisler, S.; Johnsen, H.; Hastie, T.; Eisen, M.B.; van de Rijn, M.; Jeffrey, S.S.; et al. Gene expression patterns of breast carcinomas distinguish tumor subclasses with clinical implications. Proc. Natl. Acad. Sci. USA 2001, 98, 10869-10874. [CrossRef]

9. Sotiriou, C.; Neo, S.Y.; McShane, L.M.; Korn, E.L.; Long, P.M.; Jazaeri, A.; Martiat, P.; Fox, S.B.; Harris, A.L.; Liu, E.T. Breast cancer classification and prognosis based on gene expression profiles from a population-based study. Proc. Natl. Acad. Sci. USA 2003, 100, 10393-10398. [CrossRef]

10. Veer, L.J.V.T.; Dai, H.; van de Vijver, M.J.; He, Y.D.; Hart, A.A.; Mao, M.; Peterse, H.L.; van der Kooy, K.; Marton, M.J.; Witteveen, A.T.; et al. Gene expression profiling predicts clinical outcome of breast cancer. Nature 2002, 415, 530-536. [CrossRef]

11. Carey, L.A.; Perou, C.M.; Livasy, C.A.; Dressler, L.G.; Cowan, D.; Conway, K.; Karaca, G.; Troester, M.A.; Tse, C.K.; Edmiston, S.; et al. Race, breast cancer subtypes, and survival in the Carolina Breast Cancer Study. JAMA 2006, 295, 2492-2502. [CrossRef]

12. Guarneri, V.; Conte, P. Metastatic breast cancer: Therapeutic options according to molecular subtypes and prior adjuvant therapy. Oncologist 2009, 14, 645-656. [CrossRef] [PubMed]

13. Kennecke, H.; Yerushalmi, R.; Woods, R.; Cheang, M.C.; Voduc, D.; Speers, C.H.; Nielsen, T.O.; Gelmon, K. Metastatic behavior of breast cancer subtypes. J. Clin. Oncol. 2010, 28, 3271-3277. [CrossRef] [PubMed]

14. Nishimura, R.; Osako, T.; Okumura, Y.; Hayashi, M.; Toyozumi, Y.; Arima, N. Ki-67 as a prognostic marker according to breast cancer subtype and a predictor of recurrence time in primary breast cancer. Exp. Ther. Med. 2010, 1, 747-754. [CrossRef] [PubMed]

15. Ellis, M.J.; Tao, Y.; Luo, J.; A’Hern, R.; Evans, D.B.; Bhatnagar, A.S.; Chaudri Ross, H.A.; von Kameke, A.; Miller, W.R.; Smith, I.; et al. Outcome prediction for estrogen receptor-positive breast cancer based on postneoadjuvant endocrine therapy tumor characteristics. J. Natl. Cancer Inst. 2008, 100, 1380-1388. [CrossRef] [PubMed]

16. Cancer Genome Atlas Network. Comprehensive molecular portraits of human breast tumours. Nature 2012, 490, 61-70. [CrossRef]

17. Ellis, M.J.; Ding, L.; Shen, D.; Luo, J.; Suman, V.J.; Wallis, J.W.; Van Tine, B.A.; Hoog, J.; Goiffon, R.J.; Goldstein, T.C.; et al. Whole-genome analysis informs breast cancer response to aromatase inhibition. Nature 2012, 486, 353-360. [CrossRef]

18. Nielsen, K.V.; Ejlertsen, B.; Muller, S.; Moller, S.; Rasmussen, B.B.; Balslev, E.; Laenkholm, A.V.; Christiansen, P.; Mouridsen, H.T. Amplification of ESR1 may predict resistance to adjuvant tamoxifen in postmenopausal patients with hormone receptor positive breast cancer. Breast Cancer Res. Treat. 2011, 127, 345-355. [CrossRef]

19. Cardoso, F.; Kyriakides, S.; Ohno, S.; Penault-Llorca, F.; Poortmans, P.; Rubio, I.T.; Zackrisson, S.; Senkus, E. Early breast cancer: ESMO Clinical Practice Guidelines for diagnosis, treatment and follow-updagger. Ann. Oncol. 2019, 30, 1194-1220. [CrossRef]

20. Najim, O.; Seghers, S.; Sergoynne, L.; Van Gaver, H.; Papadimitriou, K.; Wouters, K.; Trinh, X.B.; Huizing, M.T.; Tjalma, W. The association between type of endocrine therapy and development of estrogen receptor-1 mutation(s) in patients with hormone-sensitive advanced breast cancer: A systematic review and meta-analysis of randomized and non-randomized trials. Biochim. Biophys. Acta. Rev. Cancer 2019, 1872, 188315. [CrossRef]

21. Tabarestani, S.; Motallebi, M.; Akbari, M.E. Are Estrogen Receptor Genomic Aberrations Predictive of Hormone Therapy Response in Breast Cancer? Iran. J. Cancer Prev. 2016, 9, e6565. [CrossRef]

22. Early Breast Cancer Trialists' Collaborative Group (EBCTCG); Davies, C.; Godwin, J.; Gray, R.; Clarke, M.; Cutter, D.; Darby, S.; McGale, P.; Pan, H.C.; Taylor, C.; et al. Relevance of breast cancer hormone receptors and other factors to the efficacy of adjuvant tamoxifen: Patient-level meta-analysis of randomised trials. Lancet 2011, 378, 771-784. [CrossRef] [PubMed]

23. Ma, C.X.; Reinert, T.; Chmielewska, I.; Ellis, M.J. Mechanisms of aromatase inhibitor resistance. Nat. Rev. Cancer 2015, 15, 261-275. [CrossRef] [PubMed]

24. Osborne, C.K.; Bardou, V.; Hopp, T.A.; Chamness, G.C.; Hilsenbeck, S.G.; Fuqua, S.A.; Wong, J.; Allred, D.C.; Clark, G.M.; Schiff, R. Role of the estrogen receptor coactivator AIB1 (SRC-3) and HER-2/neu in tamoxifen resistance in breast cancer. J. Natl. Cancer Inst. 2003, 95, 353-361. [CrossRef] [PubMed]

25. Arpino, G.; Green, S.J.; Allred, D.C.; Lew, D.; Martino, S.; Osborne, C.K.; Elledge, R.M. HER-2 amplification, HER-1 expression, and tamoxifen response in estrogen receptor-positive metastatic breast cancer: A southwest oncology group study. Clin. Cancer Res. 2004, 10, 5670-5676. [CrossRef] [PubMed] 
26. Osborne, C.K.; Neven, P.; Dirix, L.Y.; Mackey, J.R.; Robert, J.; Underhill, C.; Schiff, R.; Gutierrez, C.; Migliaccio, I.; Anagnostou, V.K.; et al. Gefitinib or placebo in combination with tamoxifen in patients with hormone receptor-positive metastatic breast cancer: A randomized phase II study. Clin. Cancer Res. 2011, 17, 1147-1159. [CrossRef]

27. Thangavel, C.; Dean, J.L.; Ertel, A.; Knudsen, K.E.; Aldaz, C.M.; Witkiewicz, A.K.; Clarke, R.; Knudsen, E.S. Therapeutically activating RB: Reestablishing cell cycle control in endocrine therapy-resistant breast cancer. Endocr. Relat. Cancer 2011, 18, 333-345. [CrossRef]

28. Ma, C.X.; Gao, F.; Luo, J.; Northfelt, D.W.; Goetz, M.; Forero, A.; Hoog, J.; Naughton, M.; Ademuyiwa, F.; Suresh, R.; et al. NeoPalAna: Neoadjuvant Palbociclib, a Cyclin-Dependent Kinase 4/6 Inhibitor, and Anastrozole for Clinical Stage 2 or 3 Estrogen Receptor-Positive Breast Cancer. Clin. Cancer Res. 2017, 23, 4055-4065. [CrossRef]

29. Lefebvre, C.; Bachelot, T.; Filleron, T.; Pedrero, M.; Campone, M.; Soria, J.C.; Massard, C.; Levy, C.; Arnedos, M.; Lacroix-Triki, M.; et al. Mutational Profile of Metastatic Breast Cancers: A Retrospective Analysis. PLoS Med. 2016, 13, e1002201. [CrossRef]

30. Dahlman-Wright, K.; Cavailles, V.; Fuqua, S.A.; Jordan, V.C.; Katzenellenbogen, J.A.; Korach, K.S.; Maggi, A.; Muramatsu, M.; Parker, M.G.; Gustafsson, J.A. International Union of Pharmacology. LXIV. Estrogen receptors. Pharmacol. Rev. 2006, 58, 773-781. [CrossRef]

31. Tuteja, N. Signaling through G protein coupled receptors. Plant Signal. Behav. 2009, 4, 942-947. [CrossRef]

32. Gelsomino, L.; Gu, G.; Rechoum, Y.; Beyer, A.R.; Pejerrey, S.M.; Tsimelzon, A.; Wang, T.; Huffman, K.; Ludlow, A.; Ando, S.; et al. ESR1 mutations affect anti-proliferative responses to tamoxifen through enhanced cross-talk with IGF signaling. Breast Cancer Res. Treat. 2016, 157, 253-265. [CrossRef] [PubMed]

33. Robinson, D.R.; Wu, Y.M.; Vats, P.; Su, F.; Lonigro, R.J.; Cao, X.; Kalyana-Sundaram, S.; Wang, R.; Ning, Y.; Hodges, L.; et al. Activating ESR1 mutations in hormone-resistant metastatic breast cancer. Nat. Genet. 2013, 45, 1446-1451. [CrossRef] [PubMed]

34. Toy, W.; Shen, Y.; Won, H.; Green, B.; Sakr, R.A.; Will, M.; Li, Z.; Gala, K.; Fanning, S.; King, T.A.; et al. ESR1 ligand-binding domain mutations in hormone-resistant breast cancer. Nat. Genet. 2013, 45, 1439-1445. [CrossRef] [PubMed]

35. Sefrioui, D.; Perdrix, A.; Sarafan-Vasseur, N.; Dolfus, C.; Dujon, A.; Picquenot, J.M.; Delacour, J.; Cornic, M.; Bohers, E.; Leheurteur, M.; et al. Short report: Monitoring ESR1 mutations by circulating tumor DNA in aromatase inhibitor resistant metastatic breast cancer. Int. J. Cancer 2015, 137, 2513-2519. [CrossRef]

36. Niu, J.; Andres, G.; Kramer, K.; Kundranda, M.N.; Alvarez, R.H.; Klimant, E.; Parikh, A.R.; Tan, B.; Staren, E.D.; Markman, M. Incidence and clinical significance of ESR1 mutations in heavily pretreated metastatic breast cancer patients. Onco Targets Ther. 2015, 8, 3323-3328. [CrossRef]

37. Pejerrey, S.M.; Dustin, D.; Kim, J.A.; Gu, G.; Rechoum, Y.; Fuqua, S.A.W. The Impact of ESR1 Mutations on the Treatment of Metastatic Breast Cancer. Horm. Cancer 2018, 9, 215-228. [CrossRef]

38. Basudan, A.; Priedigkeit, N.; Hartmaier, R.J.; Sokol, E.S.; Bahreini, A.; Watters, R.J.; Boisen, M.M.; Bhargava, R.; Weiss, K.R.; Karsten, M.M.; et al. Frequent ESR1 and CDK Pathway Copy-Number Alterations in Metastatic Breast Cancer. Mol. Cancer Res. 2019, 17, 457-468. [CrossRef]

39. Brown, L.A.; Hoog, J.; Chin, S.F.; Tao, Y.; Zayed, A.A.; Chin, K.; Teschendorff, A.E.; Quackenbush, J.F.; Marioni, J.C.; Leung, S.; et al. ESR1 gene amplification in breast cancer: A common phenomenon? Nat. Genet. 2008, 40, 806-807. [CrossRef]

40. Jeselsohn, R.; Yelensky, R.; Buchwalter, G.; Frampton, G.; Meric-Bernstam, F.; Gonzalez-Angulo, A.M.; Ferrer-Lozano, J.; Perez-Fidalgo, J.A.; Cristofanilli, M.; Gomez, H.; et al. Emergence of constitutively active estrogen receptor-alpha mutations in pretreated advanced estrogen receptor-positive breast cancer. Clin. Cancer Res. 2014, 20, 1757-1767. [CrossRef]

41. Nembrot, M.; Quintana, B.; Mordoh, J. Estrogen receptor gene amplification is found in some estrogen receptor-positive human breast tumors. Biochem. Biophys. Res. Commun. 1990, 166, 601-607. [CrossRef]

42. Tomita, S.; Zhang, Z.; Nakano, M.; Ibusuki, M.; Kawazoe, T.; Yamamoto, Y.; Iwase, H. Estrogen receptor alpha gene ESR1 amplification may predict endocrine therapy responsiveness in breast cancer patients. Cancer Sci. 2009, 100, 1012-1017. [CrossRef] [PubMed]

43. Holst, F.; Stahl, P.R.; Ruiz, C.; Hellwinkel, O.; Jehan, Z.; Wendland, M.; Lebeau, A.; Terracciano, L.; Al-Kuraya, K.; Janicke, F.; et al. Estrogen receptor alpha (ESR1) gene amplification is frequent in breast cancer. Nat. Genet. 2007, 39, 655-660. [CrossRef] [PubMed] 
44. Markiewicz, A.; Welnicka-Jaskiewicz, M.; Skokowski, J.; Jaskiewicz, J.; Szade, J.; Jassem, J.; Zaczek, A.J. Prognostic significance of ESR1 amplification and ESR1 PvuII, CYP2C19*2, UGT2B15*2 polymorphisms in breast cancer patients. PLoS ONE 2013, 8, e72219. [CrossRef] [PubMed]

45. Holst, F.; Singer, C.F. ESR1-Amplification-Associated Estrogen Receptor alpha Activity in Breast Cancer. Trends Endocrinol. Metab. 2016, 27, 751-752. [CrossRef] [PubMed]

46. Giltnane, J.M.; Hutchinson, K.E.; Stricker, T.P.; Formisano, L.; Young, C.D.; Estrada, M.V.; Nixon, M.J.; Du, L.; Sanchez, V.; Ericsson, P.G.; et al. Genomic profiling of ER(+) breast cancers after short-term estrogen suppression reveals alterations associated with endocrine resistance. Sci. Transl. Med. 2017, 9. [CrossRef]

47. Veeraraghavan, J.; Tan, Y.; Cao, X.X.; Kim, J.A.; Wang, X.; Chamness, G.C.; Maiti, S.N.; Cooper, L.J.; Edwards, D.P.; Contreras, A.; et al. Recurrent ESR1-CCDC170 rearrangements in an aggressive subset of oestrogen receptor-positive breast cancers. Nat. Commun. 2014, 5, 4577. [CrossRef]

48. Lei, J.T.; Gou, X.; Seker, S.; Ellis, M.J. ESR1 alterations and metastasis in estrogen receptor positive breast cancer. J. Cancer Metastasis Treat. 2019, 5. [CrossRef]

49. Li, L.; Lin, L.; Veeraraghavan, J.; Hu, Y.; Wang, X.; Lee, S.; Tan, Y.; Schiff, R.; Wang, X.S. Therapeutic role of recurrent ESR1-CCDC170 gene fusions in breast cancer endocrine resistance. Breast Cancer Res. 2020, $22,84$. [CrossRef]

50. Ross, D.S.; Liu, B.; Schram, A.M.; Razavi, P.; Lagana, S.M.; Zhang, Y.; Scaltriti, M.; Bromberg, J.F.; Ladanyi, M.; Hyman, D.M.; et al. Enrichment of kinase fusions in ESR1 wild-type, metastatic breast cancer revealed by a systematic analysis of 4854 patients. Ann. Oncol. 2020, 31, 991-1000. [CrossRef]

51. Weis, K.E.; Ekena, K.; Thomas, J.A.; Lazennec, G.; Katzenellenbogen, B.S. Constitutively active human estrogen receptors containing amino acid substitutions for tyrosine 537 in the receptor protein. Mol. Endocrinol. 1996, 10, 1388-1398. [CrossRef]

52. Zhang, Q.X.; Borg, A.; Wolf, D.M.; Oesterreich, S.; Fuqua, S.A. An estrogen receptor mutant with strong hormone-independent activity from a metastatic breast cancer. Cancer Res. 1997, 57, 1244-1249. [PubMed]

53. Jeselsohn, R.; Bergholz, J.S.; Pun, M.; Cornwell, M.; Liu, W.; Nardone, A.; Xiao, T.; Li, W.; Qiu, X.; Buchwalter, G.; et al. Allele-Specific Chromatin Recruitment and Therapeutic Vulnerabilities of ESR1 Activating Mutations. Cancer Cell 2018, 33, 173-186.e5. [CrossRef] [PubMed]

54. Li, S.; Shen, D.; Shao, J.; Crowder, R.; Liu, W.; Prat, A.; He, X.; Liu, S.; Hoog, J.; Lu, C.; et al. Endocrine-therapy-resistant ESR1 variants revealed by genomic characterization of breast-cancer-derived xenografts. Cell Rep. 2013, 4, 1116-1130. [CrossRef] [PubMed]

55. Merenbakh-Lamin, K.; Ben-Baruch, N.; Yeheskel, A.; Dvir, A.; Soussan-Gutman, L.; Jeselsohn, R.; Yelensky, R.; Brown, M.; Miller, V.A.; Sarid, D.; et al. D538G mutation in estrogen receptor-alpha: A novel mechanism for acquired endocrine resistance in breast cancer. Cancer Res. 2013, 73, 6856-6864. [CrossRef]

56. Pavlin, M.; Spinello, A.; Pennati, M.; Zaffaroni, N.; Gobbi, S.; Bisi, A.; Colombo, G.; Magistrato, A. A Computational Assay of Estrogen Receptor alpha Antagonists Reveals the Key Common Structural Traits of Drugs Effectively Fighting Refractory Breast Cancers. Sci. Rep. 2018, 8, 649. [CrossRef] [PubMed]

57. Gates, L.A.; Gu, G.; Chen, Y.; Rohira, A.D.; Lei, J.T.; Hamilton, R.A.; Yu, Y.; Lonard, D.M.; Wang, J.; Wang, S.P.; et al. Proteomic profiling identifies key coactivators utilized by mutant ERalpha proteins as potential new therapeutic targets. Oncogene 2018, 37, 4581-4598. [CrossRef]

58. Razavi, P.; Chang, M.T.; Xu, G.; Bandlamudi, C.; Ross, D.S.; Vasan, N.; Cai, Y.; Bielski, C.M.; Donoghue, M.T.A.; Jonsson, P.; et al. The Genomic Landscape of Endocrine-Resistant Advanced Breast Cancers. Cancer Cell 2018, 34, 427-438.e6. [CrossRef]

59. Li, Z.; Levine, K.M.; Bahreini, A.; Wang, P.; Chu, D.; Park, B.H.; Oesterreich, S.; Lee, A.V. Upregulation of IRS1 Enhances IGF1 Response in Y537S and D538G ESR1 Mutant Breast Cancer Cells. Endocrinology 2018, 159, 285-296. [CrossRef]

60. Osborne, C.K.; Schiff, R. Mechanisms of endocrine resistance in breast cancer. Annu. Rev. Med. 2011, 62, 233-247. [CrossRef]

61. Bahreini, A.; Li, Z.; Wang, P.; Levine, K.M.; Tasdemir, N.; Cao, L.; Weir, H.M.; Puhalla, S.L.; Davidson, N.E.; Stern, A.M.; et al. Mutation site and context dependent effects of ESR1 mutation in genome-edited breast cancer cell models. Breast Cancer Res. 2017, 19, 60. [CrossRef] 
62. Clatot, F.; Perdrix, A.; Beaussire, L.; Lequesne, J.; Levy, C.; Emile, G.; Bubenheim, M.; Lacaille, S.; Calbrix, C.; Augusto, L.; et al. Risk of early progression according to circulating ESR1 mutation, CA-15.3 and cfDNA increases under first-line anti-aromatase treatment in metastatic breast cancer. Breast Cancer Res. 2020, $22,56$. [CrossRef] [PubMed]

63. Goldberg, J.; Qiao, N.; Gross, B.; Meric-Bernstam, F.; Guerriero, J.; Chen, K.; Philips, A.V.; Peoples, G.E.; Alatrash, G.; Mittendorf, E.A. ESR1 mutations provide novel targets for breast cancer immunotherapy. J. Clin. Oncol. 2020, 38, 3135. [CrossRef]

64. Lee, J.H.; Jeong, H.; Choi, J.W.; Oh, H.E.; Kim, Y.S. Liquid biopsy prediction of axillary lymph node metastasis, cancer recurrence, and patient survival in breast cancer: A meta-analysis. Med. Baltim. 2018, 97, e12862. [CrossRef] [PubMed]

65. Cornen, S.; Guille, A.; Adelaide, J.; Addou-Klouche, L.; Finetti, P.; Saade, M.R.; Manai, M.; Carbuccia, N.; Bekhouche, I.; Letessier, A.; et al. Candidate luminal B breast cancer genes identified by genome, gene expression and DNA methylation profiling. PLoS ONE 2014, 9, e81843. [CrossRef] [PubMed]

66. McDonough, S.J.; Bhagwate, A.; Sun, Z.; Wang, C.; Zschunke, M.; Gorman, J.A.; Kopp, K.J.; Cunningham, J.M. Use of FFPE-derived DNA in next generation sequencing: DNA extraction methods. PLoS ONE 2019, 14, e0211400. [CrossRef]

67. Oh, E.; Choi, Y.L.; Kwon, M.J.; Kim, R.N.; Kim, Y.J.; Song, J.Y.; Jung, K.S.; Shin, Y.K. Comparison of Accuracy of Whole-Exome Sequencing with Formalin-Fixed Paraffin-Embedded and Fresh Frozen Tissue Samples. PLoS ONE 2015, 10, e0144162. [CrossRef] [PubMed]

68. Wong, S.Q.; Li, J.; Tan, A.Y.; Vedururu, R.; Pang, J.M.; Do, H.; Ellul, J.; Doig, K.; Bell, A.; MacArthur, G.A.; et al. Sequence artefacts in a prospective series of formalin-fixed tumours tested for mutations in hotspot regions by massively parallel sequencing. BMC Med. Genom. 2014, 7, 23. [CrossRef]

69. Greytak, S.R.; Engel, K.B.; Zmuda, E.; Casas-Silva, E.; Guan, P.; Hoadley, K.A.; Mungall, A.J.; Wheeler, D.A.; Doddapaneni, H.V.; Moore, H.M. National Cancer Institute Biospecimen Evidence-Based Practices: Harmonizing Procedures for Nucleic Acid Extraction from Formalin-Fixed, Paraffin-Embedded Tissue. Biopreserv. Biobank. 2018, 16, 247-250. [CrossRef]

70. Kofanova, O.; Bellora, C.; Garcia Frasquilho, S.; Antunes, L.; Hamot, G.; Mathay, C.; Mommaerts, K.; Muller, A.; DeWitt, B.; Betsou, F. Standardization of the preanalytical phase of DNA extraction from fixed tissue for next-generation sequencing analyses. N. Biotechnol. 2020, 54, 52-61. [CrossRef]

71. Ivanov, M.; Laktionov, K.; Breder, V.; Chernenko, P.; Novikova, E.; Telysheva, E.; Musienko, S.; Baranova, A.; Mileyko, V. Towards standardization of next-generation sequencing of FFPE samples for clinical oncology: Intrinsic obstacles and possible solutions. J. Transl. Med. 2017, 15, 22. [CrossRef]

72. Tozaki, T.; Ohnuma, A.; Takasu, M.; Kikuchi, M.; Kakoi, H.; Hirota, K.I.; Kusano, K.; Nagata, S.I. Droplet Digital PCR Detection of the Erythropoietin Transgene from Horse Plasma and Urine for Gene-Doping Control. Genes 2019, 10. [CrossRef] [PubMed]

73. Van Ginkel, J.H.; van den Broek, D.A.; van Kuik, J.; Linders, D.; de Weger, R.; Willems, S.M.; Huibers, M.M.H. Preanalytical blood sample workup for cell-free DNA analysis using Droplet Digital PCR for future molecular cancer diagnostics. Cancer Med. 2017, 6, 2297-2307. [CrossRef] [PubMed]

74. Grolz, D.; Hauch, S.; Schlumpberger, M.; Guenther, K.; Voss, T.; Sprenger-Haussels, M.; Oelmuller, U. Liquid Biopsy Preservation Solutions for Standardized Pre-Analytical Workflows-Venous Whole Blood and Plasma. Curr. Pathobiol. Rep. 2018, 6, 275-286. [CrossRef] [PubMed]

75. Gerber, T.; Taschner-Mandl, S.; Saloberger-Sindhoringer, L.; Popitsch, N.; Heitzer, E.; Witt, V.; Geyeregger, R.; Hutter, C.; Schwentner, R.; Ambros, I.M.; et al. Assessment of Pre-Analytical Sample Handling Conditions for Comprehensive Liquid Biopsy Analysis. J. Mol. Diagn. 2020, 22, 1070-1086. [CrossRef]

76. Kang, Q.; Henry, N.L.; Paoletti, C.; Jiang, H.; Vats, P.; Chinnaiyan, A.M.; Hayes, D.F.; Merajver, S.D.; Rae, J.M.; Tewari, M. Comparative analysis of circulating tumor DNA stability In K3EDTA, Streck, and CellSave blood collection tubes. Clin. Biochem. 2016, 49, 1354-1360. [CrossRef]

77. Medina Diaz, I.; Nocon, A.; Mehnert, D.H.; Fredebohm, J.; Diehl, F.; Holtrup, F. Performance of Streck cfDNA Blood Collection Tubes for Liquid Biopsy Testing. PLoS ONE 2016, 11, e0166354. [CrossRef]

78. Bartels, S.; Christgen, M.; Luft, A.; Persing, S.; Jodecke, K.; Lehmann, U.; Kreipe, H. Estrogen receptor (ESR1) mutation in bone metastases from breast cancer. Mod. Pathol. 2018, 31, 56-61. [CrossRef] 
79. Chandarlapaty, S.; Chen, D.; He, W.; Sung, P.; Samoila, A.; You, D.; Bhatt, T.; Patel, P.; Voi, M.; Gnant, M.; et al. Prevalence of ESR1 Mutations in Cell-Free DNA and Outcomes in Metastatic Breast Cancer: A Secondary Analysis of the BOLERO-2 Clinical Trial. JAMA Oncol. 2016, 2, 1310-1315. [CrossRef]

80. Chu, D.; Paoletti, C.; Gersch, C.; VanDenBerg, D.A.; Zabransky, D.J.; Cochran, R.L.; Wong, H.Y.; Toro, P.V.; Cidado, J.; Croessmann, S.; et al. ESR1 Mutations in Circulating Plasma Tumor DNA from Metastatic Breast Cancer Patients. Clin. Cancer Res. 2016, 22, 993-999. [CrossRef]

81. Clatot, F.; Perdrix, A.; Augusto, L.; Beaussire, L.; Delacour, J.; Calbrix, C.; Sefrioui, D.; Viailly, P.J.; Bubenheim, M.; Moldovan, C.; et al. Kinetics, prognostic and predictive values of ESR1 circulating mutations in metastatic breast cancer patients progressing on aromatase inhibitor. Oncotarget 2016, 7, 74448-74459. [CrossRef]

82. Fribbens, C.; O'Leary, B.; Kilburn, L.; Hrebien, S.; Garcia-Murillas, I.; Beaney, M.; Cristofanilli, M.; Andre, F.; Loi, S.; Loibl, S.; et al. Plasma ESR1 Mutations and the Treatment of Estrogen Receptor-Positive Advanced Breast Cancer. J. Clin. Oncol. 2016, 34, 2961-2968. [CrossRef] [PubMed]

83. Nik-Zainal, S.; Davies, H.; Staaf, J.; Ramakrishna, M.; Glodzik, D.; Zou, X.; Martincorena, I.; Alexandrov, L.B.; Martin, S.; Wedge, D.C.; et al. Landscape of somatic mutations in 560 breast cancer whole-genome sequences. Nature 2016, 534, 47-54. [CrossRef] [PubMed]

84. Schiavon, G.; Hrebien, S.; Garcia-Murillas, I.; Cutts, R.J.; Pearson, A.; Tarazona, N.; Fenwick, K.; Kozarewa, I.; Lopez-Knowles, E.; Ribas, R.; et al. Analysis of ESR1 mutation in circulating tumor DNA demonstrates evolution during therapy for metastatic breast cancer. Sci. Transl. Med. 2015, 7, 313ra182. [CrossRef] [PubMed]

85. Spoerke, J.M.; Gendreau, S.; Walter, K.; Qiu, J.; Wilson, T.R.; Savage, H.; Aimi, J.; Derynck, M.K.; Chen, M.; Chan, I.T.; et al. Heterogeneity and clinical significance of ESR1 mutations in ER-positive metastatic breast cancer patients receiving fulvestrant. Nat. Commun. 2016, 7, 11579. [CrossRef] [PubMed]

86. Takeshita, T.; Yamamoto, Y.; Yamamoto-Ibusuki, M.; Tomiguchi, M.; Sueta, A.; Murakami, K.; Omoto, Y.; Iwase, H. Analysis of ESR1 and PIK3CA mutations in plasma cell-free DNA from ER-positive breast cancer patients. Oncotarget 2017, 8, 52142-52155. [CrossRef] [PubMed]

87. Toy, W.; Weir, H.; Razavi, P.; Lawson, M.; Goeppert, A.U.; Mazzola, A.M.; Smith, A.; Wilson, J.; Morrow, C.; Wong, W.L.; et al. Activating ESR1 Mutations Differentially Affect the Efficacy of ER Antagonists. Cancer Discov. 2017, 7, 277-287. [CrossRef] [PubMed]

88. Wang, P.; Bahreini, A.; Gyanchandani, R.; Lucas, P.C.; Hartmaier, R.J.; Watters, R.J.; Jonnalagadda, A.R.; Trejo Bittar, H.E.; Berg, A.; Hamilton, R.L.; et al. Sensitive Detection of Mono- and Polyclonal ESR1 Mutations in Primary Tumors, Metastatic Lesions, and Cell-Free DNA of Breast Cancer Patients. Clin. Cancer Res. 2016, 22, 1130-1137. [CrossRef]

89. Yanagawa, T.; Kagara, N.; Miyake, T.; Tanei, T.; Naoi, Y.; Shimoda, M.; Shimazu, K.; Kim, S.J.; Noguchi, S. Detection of ESR1 mutations in plasma and tumors from metastatic breast cancer patients using next-generation sequencing. Breast Cancer Res. Treat. 2017, 163, 231-240. [CrossRef]

90. Gyanchandani, R.; Kota, K.J.; Jonnalagadda, A.R.; Minteer, T.; Knapick, B.A.; Oesterreich, S.; Brufsky, A.M.; Lee, A.V.; Puhalla, S.L. Detection of ESR1 mutations in circulating cell-free DNA from patients with metastatic breast cancer treated with palbociclib and letrozole. Oncotarget 2017, 8, 66901-66911. [CrossRef]

91. Laig, M.; Fekete, C.; Majumdar, N. Digital PCR and the QuantStudio 3D Digital PCR System. Methods Mol. Biol. 2020, 2065, 209-231. [CrossRef]

92. Head, S.R.; Komori, H.K.; LaMere, S.A.; Whisenant, T.; Van Nieuwerburgh, F.; Salomon, D.R.; Ordoukhanian, P. Library construction for next-generation sequencing: Overviews and challenges. Biotechniques 2014, 56, 61-64, 66, 68, passim. [CrossRef] [PubMed]

93. Van Dijk, E.L.; Jaszczyszyn, Y.; Thermes, C. Library preparation methods for next-generation sequencing: Tone down the bias. Exp. Cell Res. 2014, 322, 12-20. [CrossRef] [PubMed]

94. Pereira, R.; Oliveira, J.; Sousa, M. Bioinformatics and Computational Tools for Next-Generation Sequencing Analysis in Clinical Genetics. J. Clin. Med. 2020, 9. [CrossRef] [PubMed]

95. Sakharkar, M.K.; Chow, V.T.; Kangueane, P. Distributions of exons and introns in the human genome. Silico Biol. 2004, 4, 387-393. 
96. Hung, S.S.; Meissner, B.; Chavez, E.A.; Ben-Neriah, S.; Ennishi, D.; Jones, M.R.; Shulha, H.P.; Chan, F.C.; Boyle, M.; Kridel, R.; et al. Assessment of Capture and Amplicon-Based Approaches for the Development of a Targeted Next-Generation Sequencing Pipeline to Personalize Lymphoma Management. J. Mol. Diagn. 2018, 20, 203-214. [CrossRef]

97. Samorodnitsky, E.; Jewell, B.M.; Hagopian, R.; Miya, J.; Wing, M.R.; Lyon, E.; Damodaran, S.; Bhatt, D.; Reeser, J.W.; Datta, J.; et al. Evaluation of Hybridization Capture Versus Amplicon-Based Methods for Whole-Exome Sequencing. Hum. Mutat. 2015, 36, 903-914. [CrossRef]

98. Fu, Y.; Wu, P.H.; Beane, T.; Zamore, P.D.; Weng, Z. Elimination of PCR duplicates in RNA-seq and small RNA-seq using unique molecular identifiers. BMC Genom. 2018, 19, 531. [CrossRef]

99. Hong, J.; Gresham, D. Incorporation of unique molecular identifiers in TruSeq adapters improves the accuracy of quantitative sequencing. Biotechniques 2017, 63, 221-226. [CrossRef]

100. Bentley, D.R.; Balasubramanian, S.; Swerdlow, H.P.; Smith, G.P.; Milton, J.; Brown, C.G.; Hall, K.P.; Evers, D.J.; Barnes, C.L.; Bignell, H.R.; et al. Accurate whole human genome sequencing using reversible terminator chemistry. Nature 2008, 456, 53-59. [CrossRef]

101. Van Dijk, E.L.; Auger, H.; Jaszczyszyn, Y.; Thermes, C. Ten years of next-generation sequencing technology. Trends Genet. 2014, 30, 418-426. [CrossRef]

102. Fuller, C.W.; Middendorf, L.R.; Benner, S.A.; Church, G.M.; Harris, T.; Huang, X.; Jovanovich, S.B.; Nelson, J.R.; Schloss, J.A.; Schwartz, D.C.; et al. The challenges of sequencing by synthesis. Nat. Biotechnol. 2009, 27, 1013-1023. [CrossRef] [PubMed]

103. Kircher, M.; Heyn, P.; Kelso, J. Addressing challenges in the production and analysis of illumina sequencing data. BMC Genom. 2011, 12, 382. [CrossRef] [PubMed]

104. Zhong, Y.; Xu, F.; Wu, J.; Schubert, J.; Li, M.M. Application of Next Generation Sequencing in Laboratory Medicine. Ann. Lab. Med. 2021, 41, 25-43. [CrossRef] [PubMed]

105. Desmedt, C.; Voet, T.; Sotiriou, C.; Campbell, P.J. Next-generation sequencing in breast cancer: First take home messages. Curr. Opin. Oncol. 2012, 24, 597-604. [CrossRef] [PubMed]

106. Dressman, D.; Yan, H.; Traverso, G.; Kinzler, K.W.; Vogelstein, B. Transforming single DNA molecules into fluorescent magnetic particles for detection and enumeration of genetic variations. Proc. Natl. Acad. Sci. USA 2003, 100, 8817-8822. [CrossRef]

107. Rothberg, J.M.; Hinz, W.; Rearick, T.M.; Schultz, J.; Mileski, W.; Davey, M.; Leamon, J.H.; Johnson, K.; Milgrew, M.J.; Edwards, M.; et al. An integrated semiconductor device enabling non-optical genome sequencing. Nature 2011, 475, 348-352. [CrossRef]

108. Merriman, B.; Ion Torrent, R.; Team, D.; Rothberg, J.M. Progress in ion torrent semiconductor chip based sequencing. Electrophoresis 2012, 33, 3397-3417. [CrossRef]

109. Boland, J.F.; Chung, C.C.; Roberson, D.; Mitchell, J.; Zhang, X.; Im, K.M.; He, J.; Chanock, S.J.; Yeager, M.; Dean, M. The new sequencer on the block: Comparison of Life Technology's Proton sequencer to an Illumina HiSeq for whole-exome sequencing. Hum. Genet. 2013, 132, 1153-1163. [CrossRef]

110. Quail, M.A.; Smith, M.; Coupland, P.; Otto, T.D.; Harris, S.R.; Connor, T.R.; Bertoni, A.; Swerdlow, H.P.; Gu, Y. A tale of three next generation sequencing platforms: Comparison of Ion Torrent, Pacific Biosciences and Illumina MiSeq sequencers. BMC Genom. 2012, 13, 341. [CrossRef]

111. Van der Auwera, G.A.; Carneiro, M.O.; Hartl, C.; Poplin, R.; Del Angel, G.; Levy-Moonshine, A.; Jordan, T.; Shakir, K.; Roazen, D.; Thibault, J.; et al. From FastQ data to high confidence variant calls: The Genome Analysis Toolkit best practices pipeline. Curr. Protoc. Bioinform. 2013, 43, 11.10.11-11.10.33. [CrossRef]

112. Patel, R.K.; Jain, M. NGS QC Toolkit: A toolkit for quality control of next generation sequencing data. PLoS ONE 2012, 7, e30619. [CrossRef] [PubMed]

113. Zhou, Q.; Su, X.; Wang, A.; Xu, J.; Ning, K. QC-Chain: Fast and holistic quality control method for next-generation sequencing data. PLoS ONE 2013, 8, e60234. [CrossRef] [PubMed]

114. Del Fabbro, C.; Scalabrin, S.; Morgante, M.; Giorgi, F.M. An extensive evaluation of read trimming effects on Illumina NGS data analysis. PLoS ONE 2013, 8, e85024. [CrossRef] [PubMed]

115. Flicek, P.; Birney, E. Sense from sequence reads: Methods for alignment and assembly. Nat. Methods 2009, 6, S6-S12. [CrossRef]

116. Fonseca, N.A.; Rung, J.; Brazma, A.; Marioni, J.C. Tools for mapping high-throughput sequencing data. Bioinformatics 2012, 28, 3169-3177. [CrossRef] 
117. Miller, J.R.; Koren, S.; Sutton, G. Assembly algorithms for next-generation sequencing data. Genomics 2010, 95, 315-327. [CrossRef]

118. Li, H.; Handsaker, B.; Wysoker, A.; Fennell, T.; Ruan, J.; Homer, N.; Marth, G.; Abecasis, G.; Durbin, R.; Genome Project Data Processing, S. The Sequence Alignment/Map format and SAMtools. Bioinformatics 2009, 25, 2078-2079. [CrossRef]

119. Thorvaldsdottir, H.; Robinson, J.T.; Mesirov, J.P. Integrative Genomics Viewer (IGV): High-performance genomics data visualization and exploration. Brief. Bioinform. 2013, 14, 178-192. [CrossRef]

120. Sedlazeck, F.J.; Lee, H.; Darby, C.A.; Schatz, M.C. Piercing the dark matter: Bioinformatics of long-range sequencing and mapping. Nat. Rev. Genet. 2018, 19, 329-346. [CrossRef]

121. McKenna, A.; Hanna, M.; Banks, E.; Sivachenko, A.; Cibulskis, K.; Kernytsky, A.; Garimella, K.; Altshuler, D.; Gabriel, S.; Daly, M.; et al. The Genome Analysis Toolkit: A MapReduce framework for analyzing next-generation DNA sequencing data. Genome Res. 2010, 20, 1297-1303. [CrossRef]

122. Hwang, S.; Kim, E.; Lee, I.; Marcotte, E.M. Systematic comparison of variant calling pipelines using gold standard personal exome variants. Sci. Rep. 2015, 5, 17875. [CrossRef] [PubMed]

123. Danecek, P.; Auton, A.; Abecasis, G.; Albers, C.A.; Banks, E.; DePristo, M.A.; Handsaker, R.E.; Lunter, G.; Marth, G.T.; Sherry, S.T.; et al. The variant call format and VCFtools. Bioinformatics 2011, 27, 2156-2158. [CrossRef] [PubMed]

124. Ng, P.C.; Henikoff, S. SIFT: Predicting amino acid changes that affect protein function. Nucleic Acids Res. 2003, 31, 3812-3814. [CrossRef] [PubMed]

125. Adzhubei, I.A.; Schmidt, S.; Peshkin, L.; Ramensky, V.E.; Gerasimova, A.; Bork, P.; Kondrashov, A.S.; Sunyaev, S.R. A method and server for predicting damaging missense mutations. Nat. Methods 2010, 7, 248-249. [CrossRef] [PubMed]

126. Kircher, M.; Witten, D.M.; Jain, P.; O’Roak, B.J.; Cooper, G.M.; Shendure, J. A general framework for estimating the relative pathogenicity of human genetic variants. Nat. Genet. 2014, 46, 310-315. [CrossRef] [PubMed]

127. Gonzalez-Perez, A.; Lopez-Bigas, N. Improving the assessment of the outcome of nonsynonymous SNVs with a consensus deleteriousness score, Condel. Am. J. Hum. Genet. 2011, 88, 440-449. [CrossRef] [PubMed]

128. International HapMap, C.; Altshuler, D.M.; Gibbs, R.A.; Peltonen, L.; Altshuler, D.M.; Gibbs, R.A.; Peltonen, L.; Dermitzakis, E.; Schaffner, S.F.; Yu, F.; et al. Integrating common and rare genetic variation in diverse human populations. Nature 2010, 467, 52-58. [CrossRef]

129. Siva, N. 1000 Genomes project. Nat. Biotechnol. 2008, 26, 256. [CrossRef]

130. Lek, M.; Karczewski, K.J.; Minikel, E.V.; Samocha, K.E.; Banks, E.; Fennell, T.; O’Donnell-Luria, A.H.; Ware, J.S.; Hill, A.J.; Cummings, B.B.; et al. Analysis of protein-coding genetic variation in 60,706 humans. Nature 2016, 536, 285-291. [CrossRef]

131. Harper, P.S. The European Society of Human Genetics: Beginnings, early history and development over its first 25 years. Eur. J. Hum. Genet. 2017. [CrossRef]

132. Schwarze, K.; Buchanan, J.; Taylor, J.C.; Wordsworth, S. Are whole-exome and whole-genome sequencing approaches cost-effective? A systematic review of the literature. Genet. Med. 2018, 20, 1122-1130. [CrossRef] [PubMed]

133. Day, E.; Dear, P.H.; McCaughan, F. Digital PCR strategies in the development and analysis of molecular biomarkers for personalized medicine. Methods 2013, 59, 101-107. [CrossRef] [PubMed]

134. Tong, Y.; Shen, S.; Jiang, H.; Chen, Z. Application of Digital PCR in Detecting Human Diseases Associated Gene Mutation. Cell. Physiol. Biochem. 2017, 43, 1718-1730. [CrossRef] [PubMed]

135. Kanagal-Shamanna, R. Digital PCR: Principles and Applications. Methods Mol. Biol. 2016, 1392, 43-50. [CrossRef]

136. Mao, X.; Liu, C.; Tong, H.; Chen, Y.; Liu, K. Principles of digital PCR and its applications in current obstetrical and gynecological diseases. Am. J. Transl. Res. 2019, 11, 7209-7222.

137. Sanger, F.; Nicklen, S.; Coulson, A.R. DNA sequencing with chain-terminating inhibitors. Proc. Natl. Acad. Sci. USA 1977, 74, 5463-5467. [CrossRef]

138. Besser, J.; Carleton, H.A.; Gerner-Smidt, P.; Lindsey, R.L.; Trees, E. Next-generation sequencing technologies and their application to the study and control of bacterial infections. Clin. Microbiol. Infect. 2018, 24, 335-341. [CrossRef] 
139. Margulies, M.; Egholm, M.; Altman, W.E.; Attiya, S.; Bader, J.S.; Bemben, L.A.; Berka, J.; Braverman, M.S.; Chen, Y.J.; Chen, Z.; et al. Genome sequencing in microfabricated high-density picolitre reactors. Nature 2005, 437, 376-380. [CrossRef]

140. Metzker, M.L. Sequencing technologies-The next generation. Nat. Rev. Genet. 2010, 11, 31-46. [CrossRef]

141. Paik, S.; Shak, S.; Tang, G.; Kim, C.; Baker, J.; Cronin, M.; Baehner, F.L.; Walker, M.G.; Watson, D.; Park, T.; et al. A multigene assay to predict recurrence of tamoxifen-treated, node-negative breast cancer. N. Engl. J. Med. 2004, 351, 2817-2826. [CrossRef]

142. Andergassen, U.; Kolbl, A.C.; Mahner, S.; Jeschke, U. Real-time RT-PCR systems for CTC detection from blood samples of breast cancer and gynaecological tumour patients (Review). Oncol. Rep. 2016, 35, 1905-1915. [CrossRef] [PubMed]

143. Huang, H.S.; Tsai, C.L.; Chang, J.; Hsu, T.C.; Lin, S.; Lee, C.C. Multiplex PCR system for the rapid diagnosis of respiratory virus infection: Systematic review and meta-analysis. Clin. Microbiol. Infect. 2018, 24, 1055-1063. [CrossRef] [PubMed]

144. Jeselsohn, R.; Buchwalter, G.; De Angelis, C.; Brown, M.; Schiff, R. ESR1 mutations-a mechanism for acquired endocrine resistance in breast cancer. Nat. Rev. Clin. Oncol. 2015, 12, 573-583. [CrossRef] [PubMed]

145. Sapino, A.; Roepman, P.; Linn, S.C.; Snel, M.H.; Delahaye, L.J.; van den Akker, J.; Glas, A.M.; Simon, I.M.; Barth, N.; de Snoo, F.A.; et al. MammaPrint molecular diagnostics on formalin-fixed, paraffin-embedded tissue. J. Mol. Diagn. 2014, 16, 190-197. [CrossRef] [PubMed]

146. Conway, K.; Edmiston, S.N.; May, R.; Kuan, P.F.; Chu, H.; Bryant, C.; Tse, C.K.; Swift-Scanlan, T.; Geradts, J.; Troester, M.A.; et al. DNA methylation profiling in the Carolina Breast Cancer Study defines cancer subclasses differing in clinicopathologic characteristics and survival. Breast Cancer Res. 2014, 16, 450. [CrossRef] [PubMed]

147. Sheng, X.; Guo, Y.; Lu, Y. Prognostic role of methylated GSTP1, p16, ESR1 and PITX2 in patients with breast cancer: A systematic meta-analysis under the guideline of PRISMA. Med. Baltim. 2017, 96, e7476. [CrossRef] [PubMed]

148. Eads, C.A.; Danenberg, K.D.; Kawakami, K.; Saltz, L.B.; Blake, C.; Shibata, D.; Danenberg, P.V.; Laird, P.W. MethyLight: A high-throughput assay to measure DNA methylation. Nucleic Acids Res. 2000, $28, \mathrm{E} 32$. [CrossRef] [PubMed]

149. Widschwendter, M.; Siegmund, K.D.; Muller, H.M.; Fiegl, H.; Marth, C.; Muller-Holzner, E.; Jones, P.A.; Laird, P.W. Association of breast cancer DNA methylation profiles with hormone receptor status and response to tamoxifen. Cancer Res. 2004, 64, 3807-3813. [CrossRef]

150. Ramos, E.A.; Camargo, A.A.; Braun, K.; Slowik, R.; Cavalli, I.J.; Ribeiro, E.M.; Pedrosa Fde, O.; de Souza, E.M.; Costa, F.F.; Klassen, G. Simultaneous CXCL12 and ESR1 CpG island hypermethylation correlates with poor prognosis in sporadic breast cancer. BMC Cancer 2010, 10, 23. [CrossRef]

151. Sharma, G.; Mirza, S.; Yang, Y.H.; Parshad, R.; Hazrah, P.; Datta Gupta, S.; Ralhan, R. Prognostic relevance of promoter hypermethylation of multiple genes in breast cancer patients. Cell. Oncol. 2009, 31, 487-500. [CrossRef]

152. Berlin, K.; Koren, S.; Chin, C.S.; Drake, J.P.; Landolin, J.M.; Phillippy, A.M. Assembling large genomes with single-molecule sequencing and locality-sensitive hashing. Nat. Biotechnol. 2015, 33, 623-630. [CrossRef] [PubMed]

153. Ferrarini, M.; Moretto, M.; Ward, J.A.; Surbanovski, N.; Stevanovic, V.; Giongo, L.; Viola, R.; Cavalieri, D.; Velasco, R.; Cestaro, A.; et al. An evaluation of the PacBio RS platform for sequencing and de novo assembly of a chloroplast genome. BMC Genom. 2013, 14, 670. [CrossRef] [PubMed]

154. Van Dijk, E.L.; Jaszczyszyn, Y.; Naquin, D.; Thermes, C. The Third Revolution in Sequencing Technology. Trends Genet. 2018, 34, 666-681. [CrossRef] [PubMed]

155. Deamer, D.; Akeson, M.; Branton, D. Three decades of nanopore sequencing. Nat. Biotechnol. 2016, 34, 518-524. [CrossRef] [PubMed]

156. Weirather, J.L.; Afshar, P.T.; Clark, T.A.; Tseng, E.; Powers, L.S.; Underwood, J.G.; Zabner, J.; Korlach, J.; Wong, W.H.; Au, K.F. Characterization of fusion genes and the significantly expressed fusion isoforms in breast cancer by hybrid sequencing. Nucleic Acids Res. 2015, 43, e116. [CrossRef]

157. Elazezy, M.; Joosse, S.A. Techniques of using circulating tumor DNA as a liquid biopsy component in cancer management. Comput. Struct. Biotechnol. J. 2018, 16, 370-378. [CrossRef] 
158. O’Leary, B.; Hrebien, S.; Beaney, M.; Fribbens, C.; Garcia-Murillas, I.; Jiang, J.; Li, Y.; Huang Bartlett, C.; Andre, F.; Loibl, S.; et al. Comparison of BEAMing and Droplet Digital PCR for Circulating Tumor DNA Analysis. Clin. Chem. 2019, 65, 1405-1413. [CrossRef]

159. Cristofanilli, M.; DeMichele, A.; Giorgetti, C.; Turner, N.C.; Slamon, D.J.; Im, S.A.; Masuda, N.; Verma, S.; Loi, S.; Colleoni, M.; et al. Predictors of prolonged benefit from palbociclib plus fulvestrant in women with endocrine-resistant hormone receptor-positive/human epidermal growth factor receptor 2-negative metastatic breast cancer in PALOMA-3. Eur. J. Cancer 2018, 104, 21-31. [CrossRef]

160. Lupini, L.; Moretti, A.; Bassi, C.; Schirone, A.; Pedriali, M.; Querzoli, P.; Roncarati, R.; Frassoldati, A.; Negrini, M. High-sensitivity assay for monitoring ESR1 mutations in circulating cell-free DNA of breast cancer patients receiving endocrine therapy. Sci. Rep. 2018, 8, 4371. [CrossRef]

161. Shatsky, R.; Parker, B.A.; Bui, N.Q.; Helsten, T.; Schwab, R.B.; Boles, S.G.; Kurzrock, R. Next-Generation Sequencing of Tissue and Circulating Tumor DNA: The UC San Diego Moores Center for Personalized Cancer Therapy Experience with Breast Malignancies. Mol. Cancer Ther. 2019, 18, 1001-1011. [CrossRef]

Publisher's Note: MDPI stays neutral with regard to jurisdictional claims in published maps and institutional affiliations.

(C) 2020 by the authors. Licensee MDPI, Basel, Switzerland. This article is an open access article distributed under the terms and conditions of the Creative Commons Attribution (CC BY) license (http://creativecommons.org/licenses/by/4.0/). 